\title{
Autocrine Acetylcholine, Induced by IL-17A via NFkB and ERK1/2 Pathway Activation, Promotes MUC5AC and IL-8 Synthesis in Bronchial Epithelial Cells
}

\author{
Angela Marina Montalbano, ${ }^{1}$ Giusy Daniela Albano, ${ }^{1}$ \\ Anna Bonanno, ${ }^{1}$ Loredana Riccobono, ${ }^{1}$ Caterina Di Sano, ${ }^{1}$ \\ Maria Ferraro, ${ }^{1}$ Liboria Siena, ${ }^{1}$ Giulia Anzalone, ${ }^{1,2}$ Rosalia Gagliardo, ${ }^{1}$ \\ Michael Paul Pieper, ${ }^{3}$ Mark Gjomarkaj, ${ }^{1}$ and Mirella Profita ${ }^{1}$ \\ ${ }^{1}$ Institute of Biomedicine and Molecular Immunology "A. Monroy" (IBIM), National Research Council of Italy (CNR), \\ 90146 Palermo, Italy \\ ${ }^{2}$ Dipartimento di Biomedicina Sperimentale e Neuroscienze Cliniche (BioNec), 90127 Palermo, Italy \\ ${ }^{3}$ Boehringer Ingelheim Pharma GmbH \& Co. KG, 88400 Biberach, Germany
}

Correspondence should be addressed to Mirella Profita; profita@ibim.cnr.it

Received 7 January 2016; Revised 7 April 2016; Accepted 18 April 2016

Academic Editor: Donna-Marie McCafferty

Copyright (C) 2016 Angela Marina Montalbano et al. This is an open access article distributed under the Creative Commons Attribution License, which permits unrestricted use, distribution, and reproduction in any medium, provided the original work is properly cited.

\begin{abstract}
IL-17A is overexpressed in the lung during acute neutrophilic inflammation. Acetylcholine (ACh) increases IL-8 and Muc5AC production in airway epithelial cells. We aimed to characterize the involvement of nonneuronal components of cholinergic system on IL-8 and Muc5AC production in bronchial epithelial cells stimulated with IL-17A. Bronchial epithelial cells were stimulated with recombinant human IL-17A (rhIL-17A) to evaluate the ChAT expression, the ACh binding and production, the IL-8 release, and the Muc5AC production. Furthermore, the effectiveness of PD098,059 (inhibitor of MAPKK activation), Bayll-7082 (inhibitor of $\mathrm{IkB} \alpha$ phosphorylation), Hemicholinium-3 (HCh-3) (choline uptake blocker), and Tiotropium bromide (Spiriva ${ }^{\circledR}$ ) (anticholinergic drug) was tested in our in vitro model. We showed that rhIL-17A increased the expression of ChAT, the levels of ACh binding and production, and the IL- 8 and Muc5AC production in stimulated bronchial epithelial cells compared with untreated cells. The pretreatment of the cells with PD098,059 and Bayll-7082 decreased the ChAT expression and the ACh production/binding, while HCh-3 and Tiotropium decreased the IL- 8 and Muc5AC synthesis in bronchial epithelial cells stimulated with rhIL-17A. IL-17A is involved in the IL-8 and Muc5AC production promoting, via NF $\kappa$ B and ERK1/2 pathway activation, the synthesis of ChAT, and the related activity of autocrine ACh in bronchial epithelial cells.
\end{abstract}

\section{Introduction}

Epithelial cells can contribute to chronic inflammatory disorders, synthesizing and secreting a variety of proinflammatory cytokines, such as IL-8, which regulates the neutrophil accumulation in the airways of Chronic Obstructive Pulmonary Disease (COPD) subjects $[1,2]$. In response to proinflammatory stimuli, IL-8 production is dependent on MAPK and NFKB in epithelial cells [3]. In addition, in human bronchial epithelial cells, the $\mathrm{NF} \kappa \mathrm{B}$ activation may regulate IL-8 release via ERK/MAP kinase-dependent or kinase-independent processes [4].

Airway epithelial cells contribute to inflammatory process of the airway producing mucins. Muc5AC is the most expressed mucin in the airway epithelium. Cigarette smoke, source of oxidative stress in the airways, is able to induce mucin synthesis in epithelial cells and a subsequent goblet cell production [5]. The mucociliary dysfunction component 
of COPD is due to mucus hypersecretion coupled with a decrease in mucus transport, and it is an important pathophysiological feature requiring appropriate treatment [6].

IL-17A, a major product of Th17 cells, is implicated in the pathogenesis of several inflammatory and autoimmune diseases [7, 8]. IL-17A is involved in the development and progression of inflammatory diseases of the airways, including allergic asthma, rhinitis, and COPD [9-11]. Recent studies have demonstrated the effect of IL-17A on IL-8 secretion in the airway epithelial cells and in airway smooth muscle cells $[9,12,13]$. Furthermore, IL-17A promotes the growth of airway epithelial cells through ERK-dependent signaling pathway [14] and is able to generate Muc $5 \mathrm{AC}$ by $\mathrm{NF} \kappa \mathrm{B}$ in bronchial epithelial cells [15].

Acetylcholine (ACh) is involved in airway inflammation and remodeling processes [16-19]. It is synthesized by Choline Acetyl-Transferase (ChAT) in different cell types (macrophages, T-lymphocytes, fibroblasts, and epithelial cells) acting as an autocrine/paracrine growth factor in regulating various aspects of the innate mucosal defense mechanisms including mucociliary clearance and regulation of macrophage function [20]. Nonneuronal ACh is involved in the activation of bronchial epithelial cells and alveolar macrophages as well as in the release of chemotactic mediators for eosinophils and neutrophils. It contributes to the inflammatory processes of COPD via the activation of muscarinic receptors (MRs) M1, M2, and M3 [15, 21, 22], and it is involved in the Th17 immunity of COPD patients [23]. Cholinergic agonists promote mucociliary clearance [24] and the release of inflammatory mediators from airway epithelial cells [22]. Anticholinergic drugs, currently used in the treatment of COPD, block the activity of muscarinic receptors in the airway secretory cells and in smooth muscle, reducing vagal tone and mucus secretion in COPD [25, 26]. Furthermore, in vitro, anticholinergic drugs control the release of LTB4 in the inflammatory cells recovered from induced sputum of COPD [19].

We investigated whether IL-17A, via ERK1/2 and $\mathrm{NF} \kappa \mathrm{B}$ signal pathway activation, is able to modulate the synthesis of ChAT promoting the autocrine ACh release and binding on the cell surface of 16-HBE, in an in vitro model of bronchial epithelial cell line. Furthermore, we studied whether the autocrine ACh activity, induced by IL-17A, promotes the production of IL-8 and Muc5AC in bronchial epithelial cells. Finally, we tested the effectiveness of Tiotropium bromide (Spiriva), anticholinergic drug usually used in the treatment of COPD, in our in vitro model of bronchial inflammation.

\section{Materials and Methods}

2.1. Epithelial Cell Cultures. The SV40 large T antigentransformed 16-HBE cell line, an immortalized normal bronchial epithelial cell line, or primary normal human bronchial epithelial (N-HBE) cells (ATCC, catalog number PCS-300$010)$ were used in this study. The source and origin of $16-\mathrm{HBE}$ cells were kindly provided by Dr. D. Gruenert Laboratory (University of California, San Francisco, California) to IBIMCNR, Italy. The 16-HBE cell line retains the morphology and functions of differentiated bronchial epithelial cells. The cells represent a clonal diploid $(2 n=6)$ cell line isolated from human lung. Evidences showed that 16-HBE cells are similar to primary normal human bronchial epithelial (N-HBE) cells and to bronchial epithelial cells from bronchial brushings concerning the response to proinflammatory stimuli and anti-inflammatory drugs [27].

16-HBE cells and N-HBE cells were cultured as adherent monolayers in Eagle's minimum essential medium (MEM) supplemented with $10 \%$ heat-inactivated $\left(56^{\circ} \mathrm{C}, 30 \mathrm{~min}\right)$ fetal bovine serum (FBS), 1\% MEM (nonessential amino acids, EuroClone), $2 \mathrm{mM}$ L-glutamine, and gentamicin $250 \mu \mathrm{g} / \mathrm{mL}$ at $37^{\circ} \mathrm{C}$ in a humidified $5 \% \mathrm{CO}_{2}$ atmosphere.

2.2. Stimulation of 16-HBE and N-HBE Cells with Recombinant Human IL-17A. Viable 16-HBE and N-HBE cells $(5 \times$ $10^{5}$ ) were seeded into six-well plate in MEM 10\% FBS and cultured until confluence (70-80\%). Cells were then made quiescent by culturing for $24 \mathrm{~h}$ in MEM serum-free. The $16-$ $\mathrm{HBE}$ cells were then stimulated with rhIL-17A $(0-50 \mathrm{ng} / \mathrm{mL})$ (R\&D Systems, Minneapolis, MN, USA) for 30 minutes to test the activation of the intracellular signal pathways and for $24 \mathrm{~h}$ to evaluate the intracellular expression of ChAT (protein and mRNA), ACh expression, IL-8 release, and Muc5AC production. The N-HBE cells were stimulated with rhIL-17A $20 \mathrm{ng} / \mathrm{mL}$ for $24 \mathrm{~h}$ to evaluate the intracellular expression of ChAT (protein and mRNA), ACh expression, IL-8 release, and Muc5AC production.

2.3. Stimulation of Bronchial Epithelial Cells with Drugs and Inhibitors. We tested the effects of 2-(2-amino-3methoxyphenyl)-4h-1-benzopyran-4-one (PD098,059, an inhibitor of MAPKK activation, $25 \mu \mathrm{M}$ ) (Sigma Aldrich s.r.l., Milan, Italy) and (E)-3-(4-methylphenylsulfonyl)2-propenenitrile (Bayl1-7082, an inhibitor of $\operatorname{IkB} \alpha$ phosphorylation, $50 \mu \mathrm{M}$ ) (Sigma Aldrich s.r.l., Milan, Italy) in 16-HBE cells stimulated in the presence and absence of rhIL-17A $20 \mathrm{ng} / \mathrm{mL}$. Furthermore, we tested the effect of Hemicholinium-3 (HCh-3) (a potent and selective choline uptake blocker, $50 \mu \mathrm{M}$ ) (Sigma Aldrich, Milan, Italy) in 16$\mathrm{HBE}$ cells stimulated in the presence and absence of rhIL-17A $20 \mathrm{ng} / \mathrm{mL}$. Finally, we studied the effects of anticholinergic compound Tiotropium (Spiriva) (100 nM) (Boehringer Ingelheim Pharma GmbH \& Co. KG, Biberach, Germany) in $16-\mathrm{HBE}$ and $\mathrm{N}-\mathrm{HBE}$ cells stimulated in the presence and absence of rhIL-17A $20 \mathrm{ng} / \mathrm{mL}$. The drugs were added to the cells medium $1 \% \mathrm{FBS}\left(5 \% \mathrm{CO}_{2}\right.$ at $\left.37^{\circ} \mathrm{C}\right) 1 \mathrm{~h}$ before the stimulation with rhIL-17A.

2.4. Evaluation of ChAT Protein Expression. The expression of ChAT protein was determined in 16-HBE and N-HBE cells treated with rhIL-17A for $24 \mathrm{~h}$ or medium alone using indirect label immunofluorescence analyzed by flow cytometry (FACStar Plus analyzer, Becton Dickinson, Mountain View, CA) as previously described [28]. Furthermore, the expression of ChAT protein was measured by western blot analysis as previously described [28]. The primary mouse anti-ChAT 
antibody (MAB5270, Chemicon, Millipore) was used for both flow cytometry and western blot.

2.5. Evaluation of ChAT by Real-Time Quantitative RT-PCR. Total RNA was extracted from 16-HBE cells with TRIzol Reagent (Invitrogen) following the manufacturer's instructions and was reverse-transcribed into cDNA, using $\mathrm{M}$ MLV-RT and oligo(dT) $)_{12-18}$ primer (Invitrogen). Quantitative real-time PCR of ChAT transcripts was carried out on StepOnePlus Real-Time PCR System (Applied Biosystems, Foster City, CA, USA) using specific FAM-labeled probe and primers (prevalidated TaqMan Gene Expression Assay for ChAT, Hs00253141 ml, Assays-on-Demand, Applied Biosystems). The expression of ChAT gene was normalized to glyceraldehyde-3-phosphate dehydrogenase (GAPDH) endogenous control gene. Relative quantitation of gene expression was carried out with the comparative Ct method $\left(2^{-\Delta \Delta C t}\right)$ [29] and it was plotted as fold change compared with untreated cells as the reference sample.

2.6. Evaluation of ACh Binding. ACh binding was performed as previously described [30]. The 16-HBE cells were collected, washed in cold PBS, and incubated $1 \mathrm{~h}$ at $4^{\circ} \mathrm{C}$ with a rabbit polyclonal anti-ACh antibody (ab8884, Abcam, Cambridge, UK). This antibody specifically recognized the ACh bound to biological structures such as receptors. After washing with cold PBS, FITC-conjugated polyclonal swine anti-rabbit IgG (Dako, Glostrup, Denmark) was added to the cells for $30 \mathrm{~min}$ at $4^{\circ} \mathrm{C}$. Fluorescence-positive cells were analyzed using FACSCalibur ${ }^{\mathrm{TM}}$ flow cytometer (Becton Dickinson, Mountain View, CA, USA). The percentage of positive cells was determined from forward scatter (FS) and sideways scatter (SS) patterns. No specific binding as well as background fluorescence was detected by analyzing negative control samples. The results were expressed as fluorescence mean intensity (FMI).

2.7. Evaluation of ACh Production. ACh production was performed as previously described [30]. It was measured in protein extracts from cultured 16-HBE cells by a fluorimetric method using a commercial kit (BioVision Research Products, CA, USA, cat. \#K615-100). The kit detects choline (Ch) and total choline (TCh) by adding acetylcholine esterase to the reaction that converts $\mathrm{ACh}$ into $\mathrm{Ch}$ with sensitivity until $50 \mathrm{pmol} /$ well by plotting fluorescence readings (Ex/Em $535 / 587 \mathrm{~nm}$ ) against the standard curve. This sensitivity is correspondent to the concentration of $1 \mu \mathrm{M}$ of TCh or Ch. $\mathrm{ACh}$ was evaluated as difference between TCh and $\mathrm{Ch}$. Fluorescence intensity was read using a Wallac 1420 Victor $^{2}$ multilabel counter (PerkinElmer Life Sciences, Turku, Finland). Results were expressed as pmoli/ $\mu \mathrm{g}$ protein.

2.8. Evaluation of ERK1/2 and NFKB Activation. The activation of ERK1/2 and $\mathrm{NF} \kappa \mathrm{B}$ pathway was performed by western blot analyses as previously described [30]. We used two rabbit monoclonal antibodies against anti-phospho-ERK1/2 and against anti-phospho-IkB $\alpha$ (Cell Signaling Technology,
Beverly, MA), respectively, and an anti- $\beta$-actin antibody (Sigma, St. Louis, MO).

2.9. Total and Nuclear/Cytoplasmic Protein Extraction. The cells were washed with cold PBS and nuclear/cytoplasmic extracts were obtained using an NE-PER Nuclear and Cytoplasmic Extraction Kit (Thermo Scientific, Rockford, USA), which ensures efficient cell lysis and extraction of separate cytoplasmic and nuclear protein fractions by centrifugation. Then, 25-30 $\mu \mathrm{g}$ of the lysate was denatured under reducing conditions by boiling for $3 \mathrm{~min}$ in $50 \mathrm{mM}$ Tris- $\mathrm{HCl}$ ( $\mathrm{pH} 6.8$ ), $1 \%$ sodium dodecyl sulfate (SDS), $2 \% \beta$-mercaptoethanol, and $0.01 \%$ bromophenol blue.

2.10. Evaluation of the Nuclear Translocation of NFкB-p65. The nuclear and cytoplasmic proteins extracts were separated by SDS-polyacrylamide gel electrophoresis (PAGE) and transferred via electrophoresis onto Immobilon-P membranes (Millipore, Bedford, MA, USA). After transfer, the membranes were blocked overnight at room temperature in PBS containing 3\% BSA and 0.5\% Tween 20 and then incubated for $1 \mathrm{~h}$ at room temperature with anti-NFkBp65 (C-20) sc-372, Santa Cruz Biotechnology (Santa Cruz, CA, USA). The blot was incubated with the appropriate horseradish peroxidase-conjugated secondary $\mathrm{Ab}$.

2.11. Evaluation of Muc5AC by Flow Cytometry. Muc5AC expression was determined using indirect label immunofluorescence. 16-HBE and N-HBE cells were previously fixed with $4 \%$ paraformaldehyde in PBS, washed, and permeabilized with PBS (containing $0.1 \%$ saponin, $1 \%$ sodium azide, and $10 \%$ FBS) and incubated with primary antibody, mouse monoclonal anti-Muc5AC clone 45M1 (200 $\mu \mathrm{g} / \mathrm{mL}$, \#MS-145P, NeoMarkers, Fremont, CA). The cells were washed twice and then incubated with FITC-conjugated rabbit polyclonal anti-mouse $\operatorname{IgG~} \mathrm{F}\left(\mathrm{ab}^{\prime}\right)_{2}$ (Dako, Glostrup, Denmark) for $30 \mathrm{~min}$ at $4^{\circ} \mathrm{C}$ and then analyzed by flow cytometry analyses (FACSCalibur flow cytometer, Becton Dickinson, Mountain View, CA, USA) supported by CellQuest acquisition and data analysis software (Becton Dickinson, Mountain View, CA, USA). The cells were considered Muc5AC positive when their fluorescence 1 (FL1) was greater than a gate set to exclude all cells in the FL1 peak from an isotype matched control antibody [31].

2.12. Evaluation of Muc5AC by Western Blot Analysis. 16HBE and N-HBE cells were lysed with lysis buffer $(10 \mathrm{mM}$ Tris- $\mathrm{HCl}$ ( $\mathrm{pH} 7.4$ ), $50 \mathrm{mM} \mathrm{NaCl}, 5 \mathrm{mM}$ EDTA, and $1 \%$ NP-40 NONIDET) containing protease and phosphatases inhibitors and frozen at $-20^{\circ} \mathrm{C}$. After being defrozen, samples were centrifuged at $12000 \mathrm{rpm}$ for $20 \mathrm{~min}$, supernatants were recovered, and the protein concentration was quantified by Bradford solution. Equal amounts of cell extract proteins ( $40 \mu \mathrm{g} /$ lane) were separated via SDS-PAGE electrophoresis in $8 \%$ acrylamide-bisacrylamide $(80: 1)$ under nonreducing conditions $[32,33]$. The resulting gel was equilibrated in the transfer buffer. The proteins were then transferred electrophoretically to nitrocellulose membranes that were 
incubated with 5\% fat-free skimmed milk in PBS for $1 \mathrm{~h}$ and then incubated with the same antibody and then western blot (dilution 1:500, overnight at $4^{\circ} \mathrm{C}$ ). Subsequently, the membrane was washed and incubated for $1 \mathrm{~h}$ with a secondary antibody conjugated to HRP. After wash in PBS 1x, detection was performed with an enhanced chemiluminescence system (Ambion, Austin, TX) followed by autoradiography.

2.13. Measurement of IL-8 Production. The levels of IL-8 were determined in 16-HBE supernatants using a commercial ELISA kit (R\&D Systems, Inc., MN, USA), according to the manufactures' specifications. The lower detection limit for IL- 8 was $<5 \mathrm{pg} / \mathrm{mL}$. Furthermore, the levels of IL-8 expression were determined in $16-\mathrm{HBE}$ and $\mathrm{N}-\mathrm{HBE}$ protein extracts by western blot using a mouse monoclonal antiIL-8 (dilution $1: 100$, overnight at $4^{\circ} \mathrm{C}$ ) (sc-8427, Santa Cruz Biotechnology, Inc.) and a sheep anti-mouse IgG-HRP (dilution 1:1000) (NA931, GE Healthcare UK, Little Chalfont, Buckinghamshire, UK) as primary and secondary antibody, respectively.

2.14. RNA Interference of ChAT Protein Synthesis. Cell transfection was performed according to the manufacturer's instructions $\left(72 \mathrm{~h}\right.$ at $\left.37^{\circ} \mathrm{C}\right)$ in siPORT NeoFX Transfection Agent (Ambion, Inc., Texas, USA) diluted in Opti-MEM (Gibco Invitrogen, Milan, Italy) and ChAT siRNA $(20 \mu \mathrm{M}$, s-2969 Ambion, Inc., Texas, USA) diluted in Opti-MEM for a final concentration of $30 \mathrm{nM}$. A siRNA $(20 \mu \mathrm{M}$, Ambion, Inc., Texas, USA), containing a scrambled sequence without significant homology to the human genome, was used as negative control. Knockdown efficiency was assessed on ChAT protein expression by western blot analysis. Furthermore, the effect of ChAT siRNA was checked in IL-8 measurement and in Muc5AC production obtained as mentioned above.

2.15. Gel Images Evaluation. Gel images were taken with EPSON GT-6000 scanner and then were imported into National Institutes of Health Image analysis 1.61 program to determine band intensities. Data are expressed as arbitrary densitometric units (ADU) corrected against the density of $\beta$-actin bands.

2.16. Statistical Analysis. We tested normal distribution of the data with the Kolmogorov-Smirnov test. Analysis of variance (ANOVA) corrected with Fisher's test and $t$-test was used for comparisons. Data were expressed as mean \pm standard deviation (SD). A $p$ value $<0.05$ was considered statistically significant.

\section{Results}

3.1. rhIL-17A Increased ChAT Protein Expression and ACh Binding and Production in 16-HBE Cells. The stimulation of $16-\mathrm{HBE}$ cells with rhIL-17A (20 and $50 \mathrm{ng} / \mathrm{mL}$ for $24 \mathrm{~h}$ ) significantly increased ChAT protein expression compared with unstimulated cells by both flow cytometry (Figures 1(a) and 1(b)) and western blot analyses (Figure 1(c)). The stimulation of the cells with rhIL-17A $20 \mathrm{ng} / \mathrm{mL}$ reached the higher levels of ChAT synthesis (Figure 1). Accordingly, we showed that the levels of ChAT mRNA, obtained by RTPCR, significantly increased in 16-HBE cells stimulated with rhIL-17A $20 \mathrm{ng} / \mathrm{mL}$ compared with unstimulated cells (Figure 1(d)). Finally, we showed that rhIL-17A (20 and $50 \mathrm{ng} / \mathrm{mL}$ for $24 \mathrm{~h}$ ) significantly increased the ACh binding (Figures 2(a) and 2(b)) and production (Figure 2(c)) compared with unstimulated cells. The stimulation of the cells with rhIL$17 \mathrm{~A} 20 \mathrm{ng} / \mathrm{mL}$ reached the higher levels of ACh binding and production (Figure 2).

3.2. $N F \kappa B$ and ERK1/2 Pathway Activation. The $\operatorname{pIkB} \alpha$ and pERK1/2 were significantly increased in 16-HBE cells stimulated with rhIL-17A $20 \mathrm{ng} / \mathrm{mL}$ for $30 \mathrm{~min}$ in comparison with untreated cells, reaching higher levels when compared with the cells stimulated for $2 \mathrm{~h}$ with rhIL-17A $20 \mathrm{ng} / \mathrm{mL}$ (Figures 3(a) and 3(b)). The dose-response curve showed a significant increase of $\mathrm{pIkB} \alpha$ and $\mathrm{pERK} 1 / 2$ in $16-\mathrm{HBE}$ cells stimulated with rhIL-17A $20 \mathrm{ng} / \mathrm{mL}$ in comparison with unstimulated cells. The levels of $\mathrm{pIkB} \alpha$ and $\mathrm{pERK} 1 / 2$ shaped in $16-\mathrm{HBE}$ cells stimulated with rhIL-17A $50 \mathrm{ng} / \mathrm{mL}$ in comparison with the cells stimulated with rhIL-17A $20 \mathrm{ng} / \mathrm{mL}$ are shown in Figures 3(c) and 3(d). Finally, we showed an increase of NFאB-p65 nuclear translocation in 16-HBE cells stimulated with rhIL17A $20 \mathrm{ng} / \mathrm{mL}$ compared with untreated cells (Figure 3(e)).

3.3. Effect of ERK1/2 and $I k B \alpha$ Inhibitors. The preincubation of 16-HBE cells with PD098,059 or Bayl1-7082 significantly reduced the expression of ChAT protein in 16-HBE cells stimulated with rhIL-17A $20 \mathrm{ng} / \mathrm{mL}$ for $24 \mathrm{~h}$ by both flow cytometry (Figures 4(a) and 4(b)) and western blot analysis (Figure 4(c)). Accordingly, the pretreatment of the cells with PD098,059 and Bay11-7082 significantly decreased ACh binding (Figures 5(a) and 5(b)) and production (Figure 5(c)) in $16-\mathrm{HBE}$ cells stimulated with rhIL-17A $20 \mathrm{ng} / \mathrm{mL}$ compared with the cells stimulated with rhIL-17A alone. Finally, the use of Tiotropium significantly decreased the ACh binding in 16HBE cells stimulated with rhIL-17A $20 \mathrm{ng} / \mathrm{mL}$ compared with the cells stimulated with rhIL-17A alone (Figures 5(d) and $5(\mathrm{e}))$.

3.4. Effect of HCh-3 and Tiotropium on IL-8 Production and Muc5AC Expression. The stimulation of 16-HBE cells with rhIL-17A $20 \mathrm{ng} / \mathrm{mL}$ for $24 \mathrm{~h}$ significantly increased the levels of IL- 8 protein expression and release compared to unstimulated cells (Figure 6). The pretreatment of the cells with HCh-3 $(50 \mu \mathrm{M})$ or Tiotropium $(100 \mathrm{nM})$ significantly reduced the levels of IL-8 protein expression (Figures 6(a) and 6(b)) and release (Figure 6(c)) in 16-HBE cells stimulated with rhIL-17A $20 \mathrm{ng} / \mathrm{mL}$ compared with the cells stimulated with rhIL-17A alone. Additionally, the stimulation of 16HBE cells with rhIL-17A $20 \mathrm{ng} / \mathrm{mL}$ for $24 \mathrm{~h}$ significantly increased Muc5AC expression, compared with unstimulated cells evaluated by both flow cytometry and western blot analysis (Figure 7). The pretreatment of the cells with $\mathrm{HCh}$ $3(50 \mu \mathrm{M})$ or Tiotropium $(100 \mathrm{nM})$ significantly reduced the Muc5AC protein expression in 16-HBE cells stimulated with 


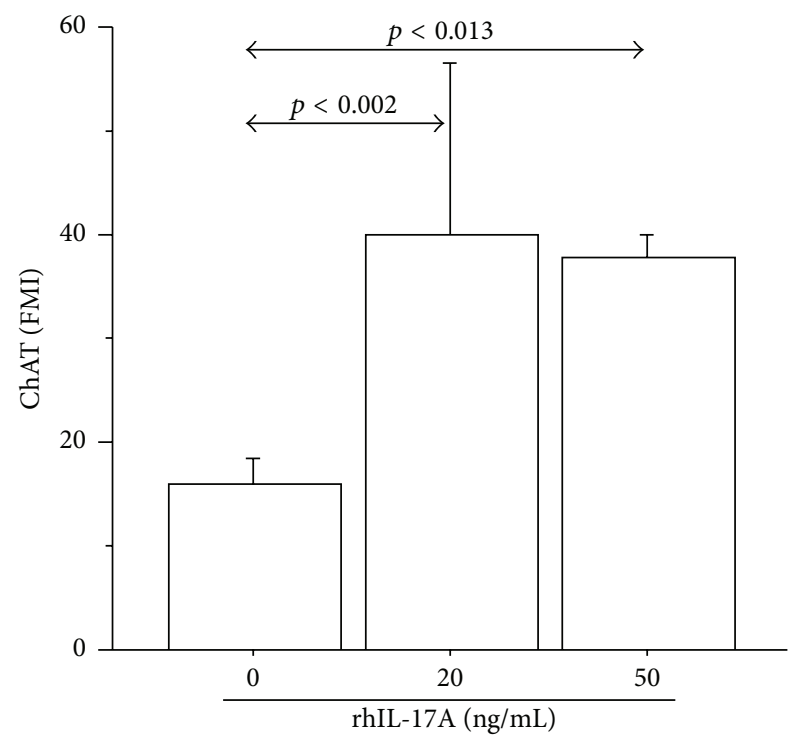

(a)

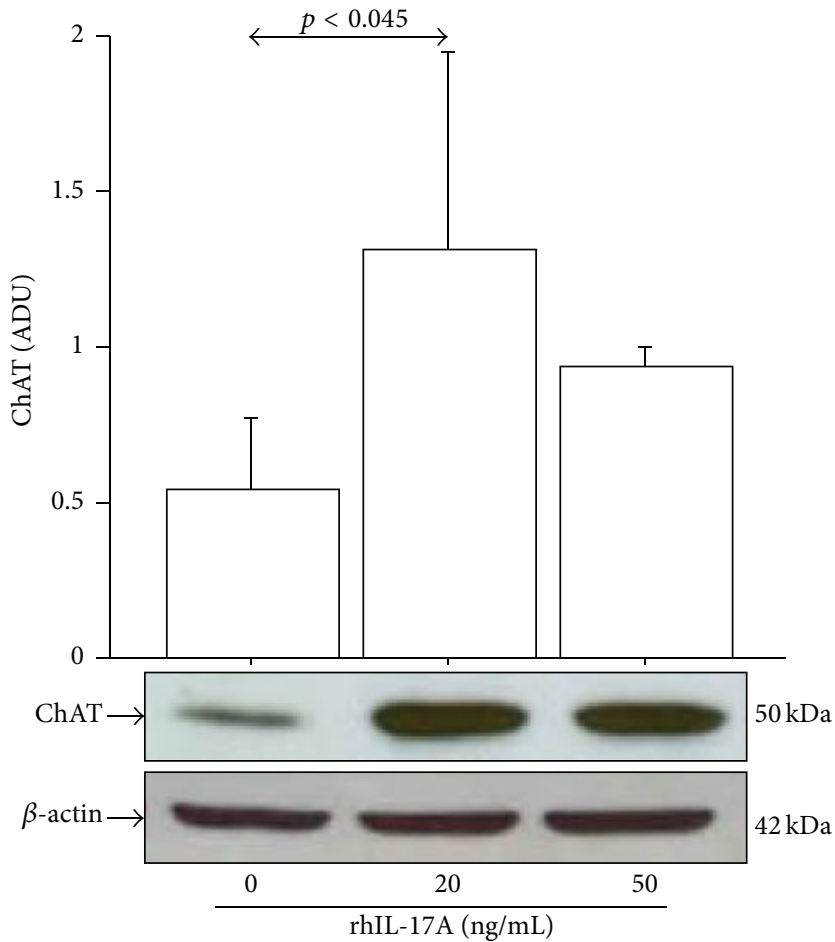

(c)

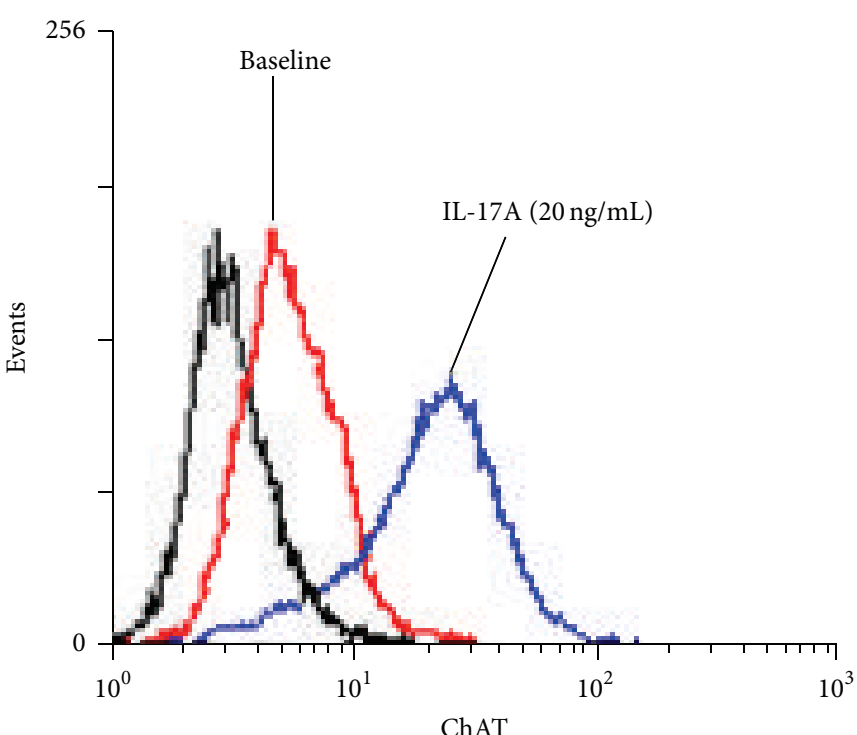

(b)

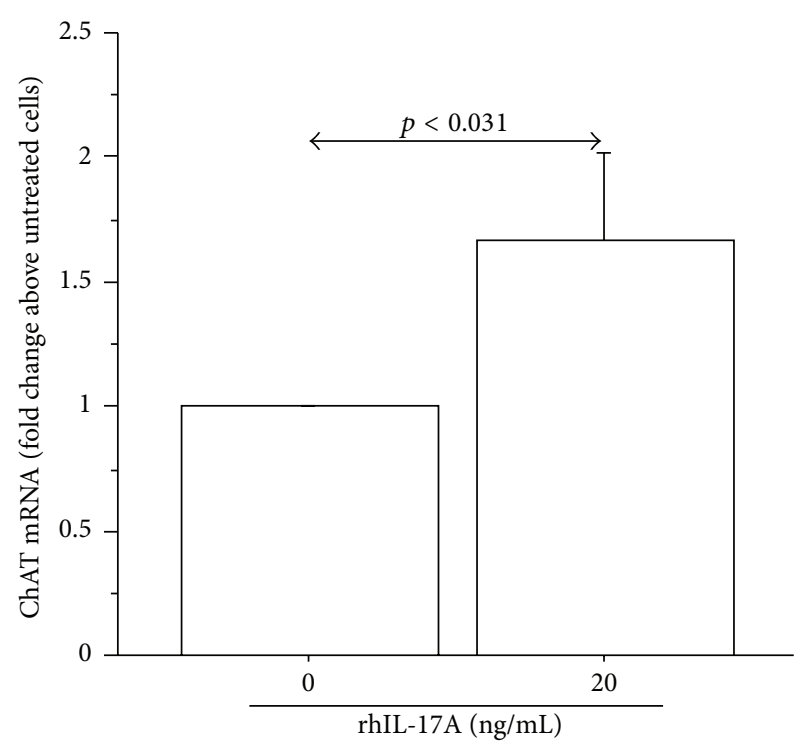

(d)

FiguRE 1: rhIL-17A increased ChAT protein expression and mRNA in 16-HBE cells. Cells were stimulated with rhIL-17A (0-50 ng/mL) for $24 \mathrm{~h}$ to evaluate ChAT protein expression (a) by flow cytometry. Bars represent mean \pm SD of fluorescence mean intensity (FMI) of three separate experiments. Representative (b) flow cytometry analysis and western blot (c) are shown. Bars represent mean \pm SD of arbitrary densitometric units (ADU). Representative western blot analysis of ChAT protein and $\beta$-actin is shown. (d) Cells were stimulated with rhIL-17A (0-20 ng/mL) for $24 \mathrm{~h}$ to evaluate ChAT mRNA levels by RT-PCR. Bars represent mean \pm SD of arbitrary units of three separate experiments and were plotted as fold change compared to untreated cells. Statistical analysis was performed by ANOVA test followed by Fisher's PLSD multiple comparison test or Student's $t$-test. The black curve represents the anti-IgG isotype negative control antibody.

rhIL-17A $20 \mathrm{ng} / \mathrm{mL}$ compared with the cells stimulated with rhIL-17A alone (Figure 7).

3.5. Effect of ChAT Silencing on Muc5AC and IL-8 Production in 16-HBE Cells. The temporary transfection of 16-HBE cells with ChAT siRNA generated a significant decrease in Muc5AC expression (Figures 8(a) and 8(b)) and IL-8 release (Figure $8(\mathrm{c})$ ) in 16-HBE cells stimulated with rhIL-17A $20 \mathrm{ng} / \mathrm{mL}$, when compared with unsilenced or scrambled cells stimulated with rhIL-17A. Knockdown efficiency of ChAT mRNA (40 $\pm 2.5 \%)$ was obtained comparing the levels of ChAT protein expression 


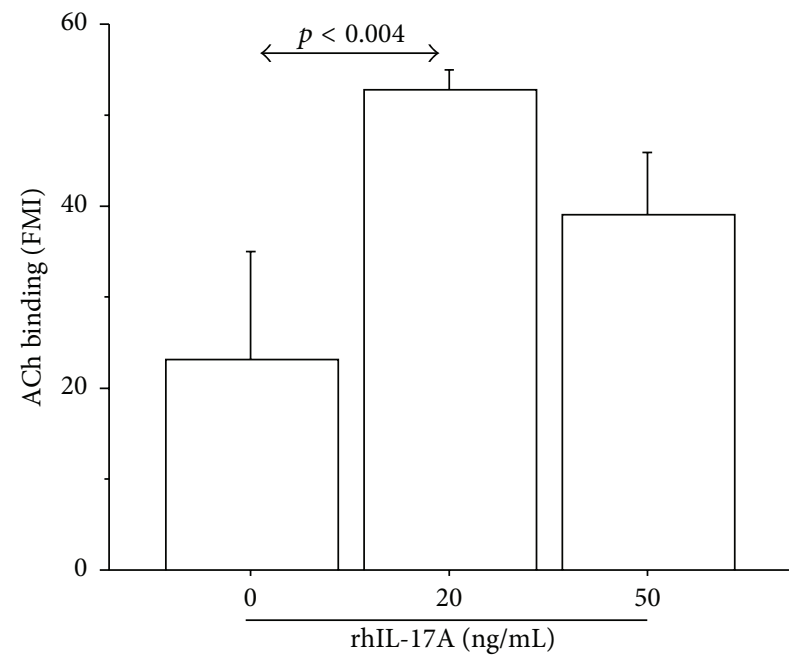

(a)

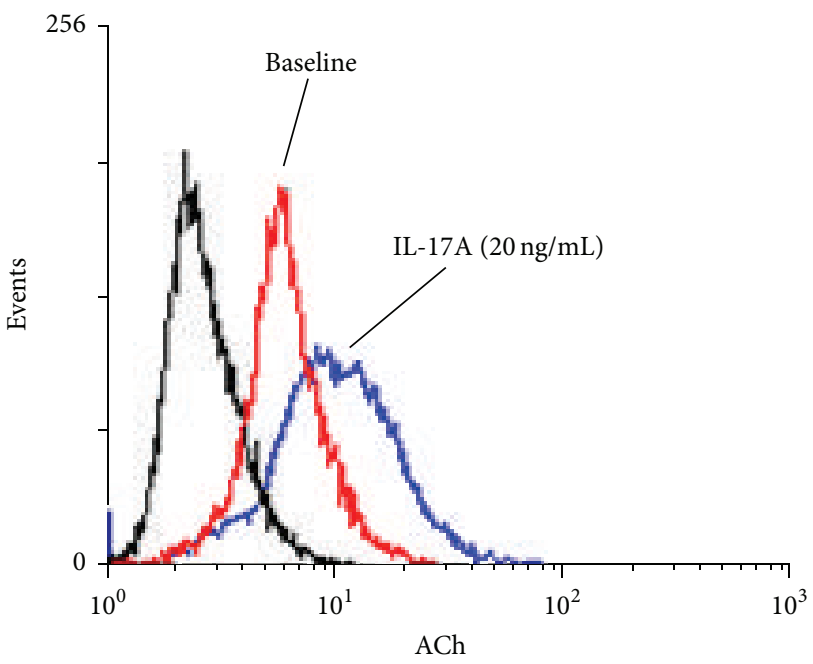

(b)

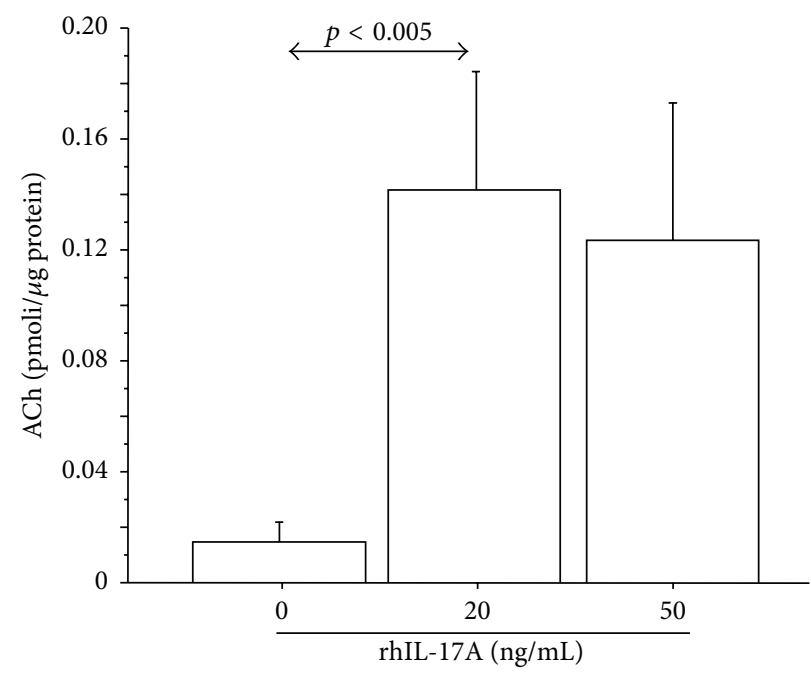

(c)

FIGURE 2: rhIL-17A increased endogenous ACh binding and production in 16-HBE cells. Cells were stimulated with rhIL-17A (0-50 ng/mL) for $24 \mathrm{~h}$ to evaluate (a) ACh binding by flow cytometry. Bars represent mean \pm SD of fluorescence mean intensity (FMI) of three separate experiments. (b) Representative flow cytometry analysis is shown. (c) ACh production expressed as pmoli/ $\mu \mathrm{g}$ protein. Bars represent mean \pm SD of three different experiments. Statistical analysis was performed by ANOVA test followed by Fisher's PLSD multiple comparison test. The black curve represents the anti-IgG isotype negative control antibody.

in silenced and scrambled unstimulated 16-HBE cells (Figure $8(d)$ ).

3.6. Effect of IL-17A on ChAT, Muc5AC, and IL-8 Production in Primary N-HBE Cells. The stimulation of N-HBE cells with rhIL-17A $20 \mathrm{ng} / \mathrm{mL}$ for $24 \mathrm{~h}$ significantly increased the levels of ChAT, Muc5AC, and IL-8 protein expression compared with unstimulated cells. The pretreatment with Tiotropium $(100 \mathrm{nM})$ significantly reduced the levels of Muc5AC and IL8 protein expression in N-HBE cells stimulated with rhIL-17A $20 \mathrm{ng} / \mathrm{mL}$ (Figure 9).

\section{Discussion}

In our in vitro model, we demonstrated for the first time that IL-17A, via ERK1/2 and $\mathrm{NF} \kappa \mathrm{B}$ pathway activation, is able to generate an increased synthesis of ChAT protein promoting ACh production and binding in human bronchial epithelial cells. The autocrine ACh activity observed in the presence of IL-17A increased the levels of IL- 8 and Muc5AC production in human bronchial epithelial cells. Finally, anticholinergic drugs such as Tiotropium (Spiriva) might have antiinflammatory and antisecretory properties by the control of ACh activity generated in bronchial epithelial cells stimulated with IL-17A.

Much of our knowledge comes from the interactions between environmental and inflammatory stimuli, and the airway epithelium has been derived extensively from in vitro cell culture models using transformed 16- $\mathrm{HBE}$ cells, representing an invaluable model in understanding the physiological properties of human airway epithelium [22, 27, 34]. In accordance with this concept, our study is based 


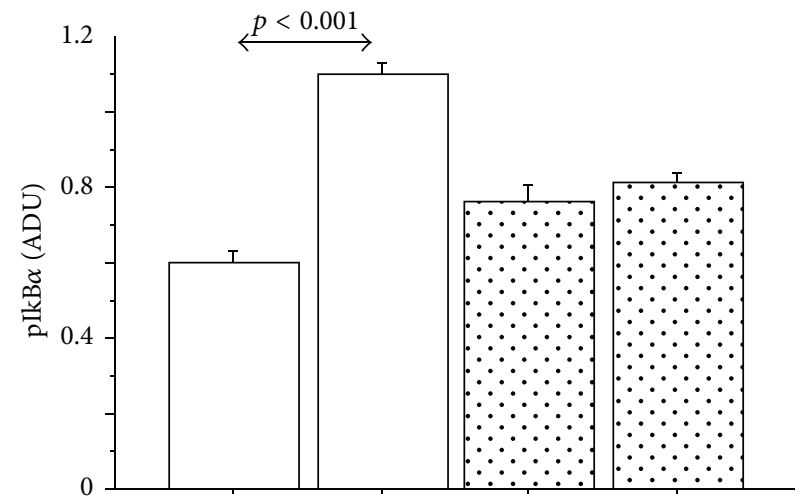

$\square 30 \mathrm{~min}$

$2 \mathrm{hrs}$

(a)
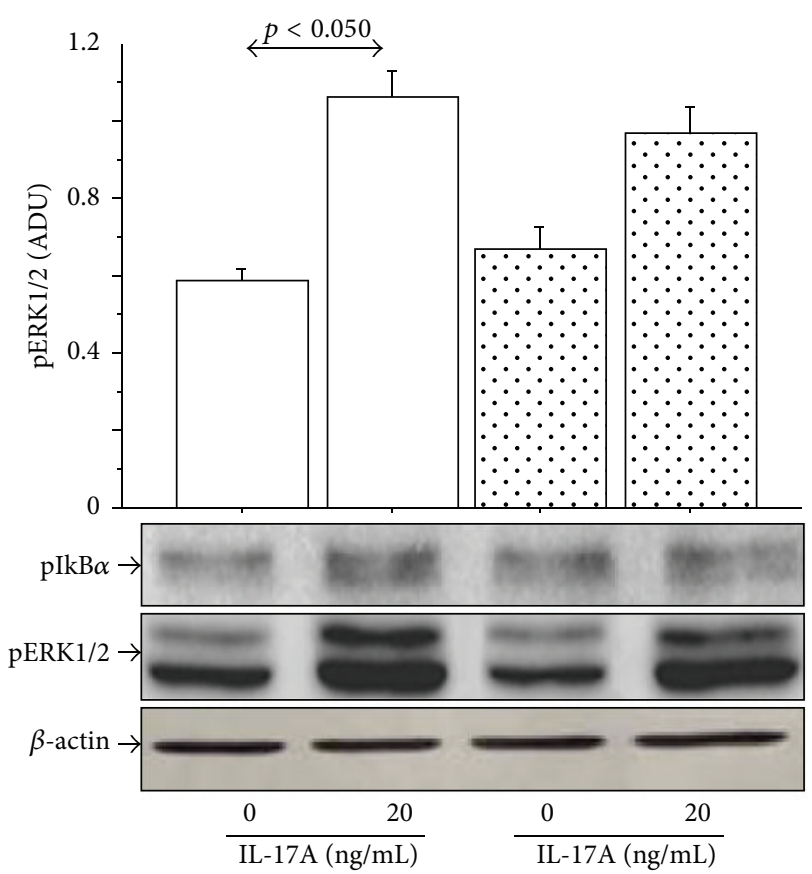

$\square 30 \mathrm{~min}$

.. $2 \mathrm{hrs}$

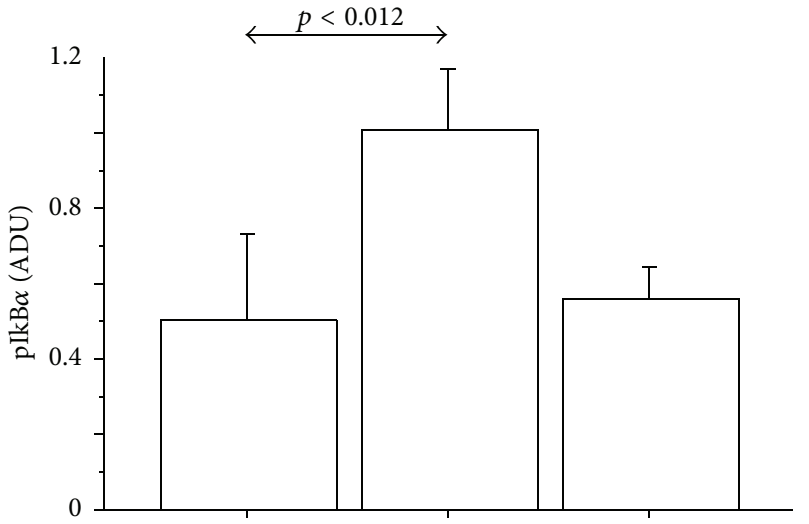

$30 \mathrm{~min}$

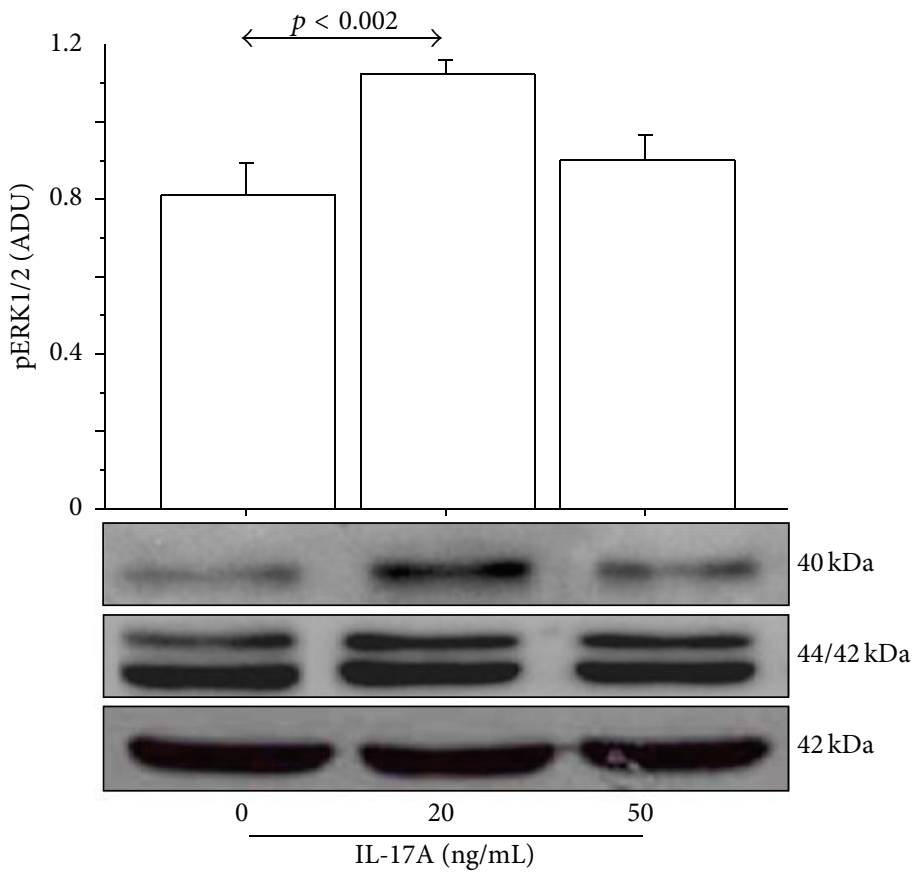

$30 \mathrm{~min}$

(b)

(d)

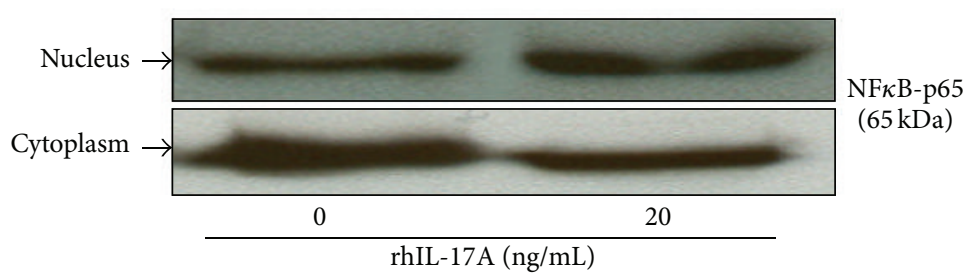

(e)

FIGURE 3: rhIL-17A increased $\mathrm{pIkB} \alpha$ and pERK1/2 in 16-HBE cells. Cells were stimulated with rhIL-17A $(0-20 \mathrm{ng} / \mathrm{mL})$ for $30 \mathrm{~min}$ and $2 \mathrm{~h}$ to evaluate (a) $\mathrm{pIkB} \alpha$ and (b) pERK1/2 by western blot. Cells were stimulated with rhIL-17A $(0-50 \mathrm{ng} / \mathrm{mL})$ for $30 \mathrm{~min}$ to evaluate (c) pIkB $\alpha$ and (d) pERK1/2 by western blot. Bars represent the mean \pm SD of arbitrary densitometric units (ADU) of three separate experiments. Representative western blot analyses of $\mathrm{pIkB} \alpha$, pERK1/2 protein, and $\beta$-actin are shown. (e) NF $\kappa \mathrm{B}$-p65 subunit in nuclear and cytosol extracts from 16-HBE cells stimulated with rhIL-17A $20 \mathrm{ng} / \mathrm{mL}$. Western blot analysis is shown. Statistical analysis was performed by Student's $t$-test and by ANOVA test followed by Fisher's PLSD multiple comparison test. 


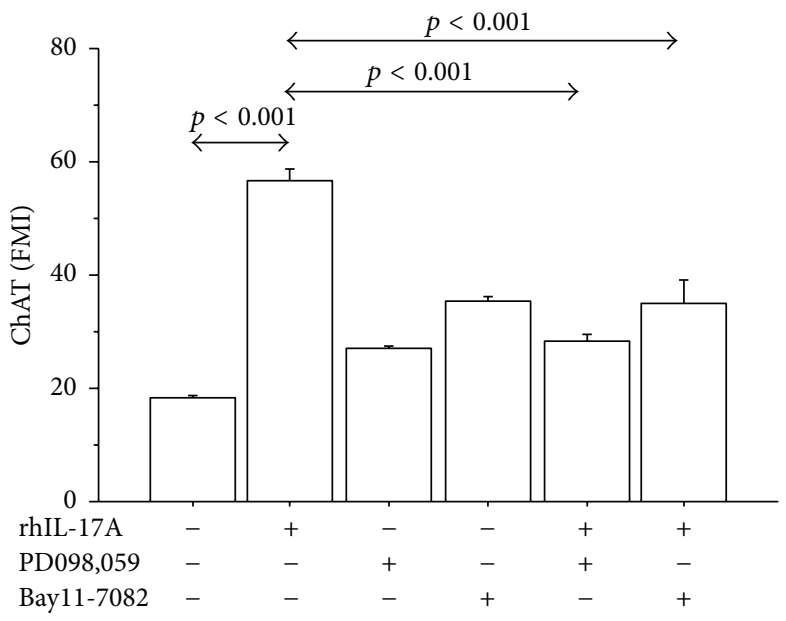

(a)

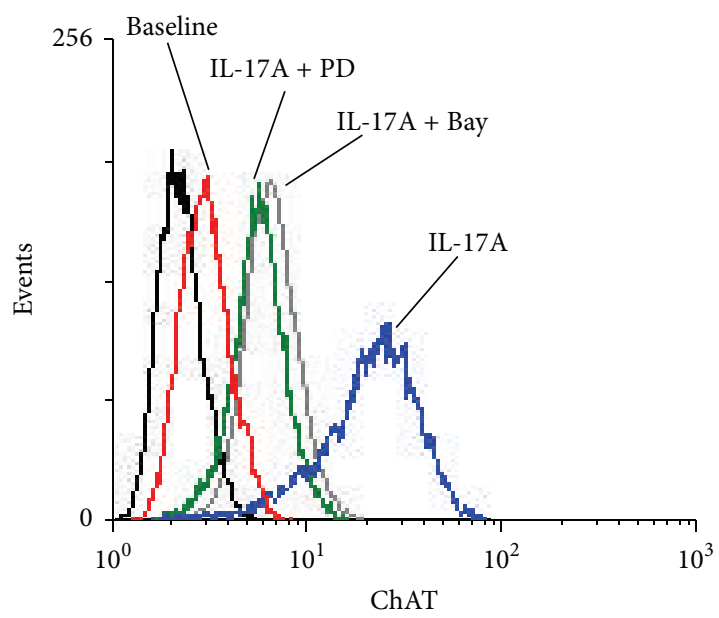

(b)

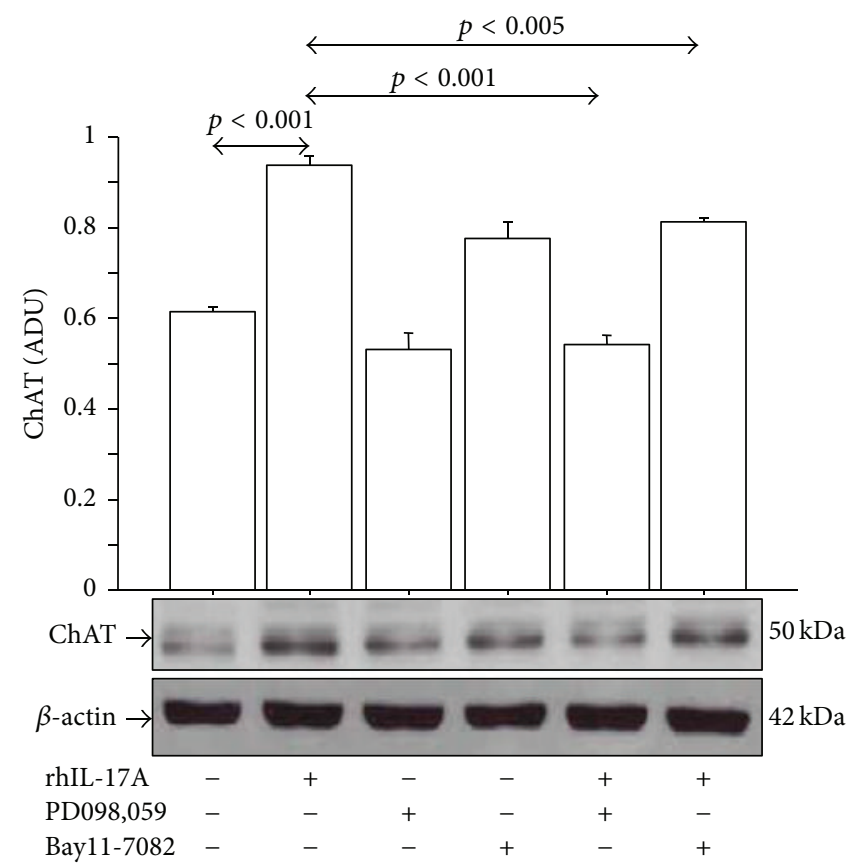

(c)

Figure 4: Effects of PD098,059 $(25 \mu \mathrm{M})$ and Bayl1-7082 $(50 \mu \mathrm{M})$ on ChAT protein expression in 16-HBE cells. Cells were preincubated for $1 \mathrm{~h}$ with PD098,059 $(25 \mu \mathrm{M})$ or Bayl1-7082 $(50 \mu \mathrm{M})$ and then stimulated with rhIL-17A $20 \mathrm{ng} / \mathrm{mL}$ for $24 \mathrm{~h}$ to evaluate ChAT protein expression (a) by flow cytometry. Bars represent mean \pm SD of fluorescence mean intensity (FMI) of three separate experiments. Representative (b) flow cytometry analysis and western blot (c) are shown. Bars represent mean \pm SD of arbitrary densitometric units (ADU). Representative western blot is shown. Statistical analysis was performed by ANOVA test followed by Fisher's PLSD multiple comparison test. The black curve represents the anti-IgG isotype negative control antibody.

principally on the use of an immortalized airway epithelial cell line, 16-HBE. Nevertheless, to strengthen the message of our findings we performed some experiments using commercially available primary bronchial epithelial cells.

ACh, classically known as a parasympathetic neurotransmitter, is able to affect the inflammatory processes in COPD $[19,22,35]$. Th17 cells producing IL-17A are associated with nonneuronal $\mathrm{ACh}$ in the systemic inflammation of COPD patients [23]. The stimulation of cholinergic receptors enhances IL-10 and IL-17A and inhibits IFN- $\gamma$ secretion in murine spleen T-cells suggesting a link between T-cell, cholinergic receptors, and Th17 lineages [36]. Furthermore, it was observed that IL-17A is a proinflammatory cytokine involved in modulating airway immune response in several aspects covering both the innate and the adaptive immunity in chronic lung disorders [37-39]. Bronchial epithelial cells from COPD patients as well as 16-HBE cell line express IL-17 receptor [40]. In light of this background, we hypothesized a link between IL-17A and the production of autocrine growth factor ACh in bronchial epithelial cells. Accordingly, 


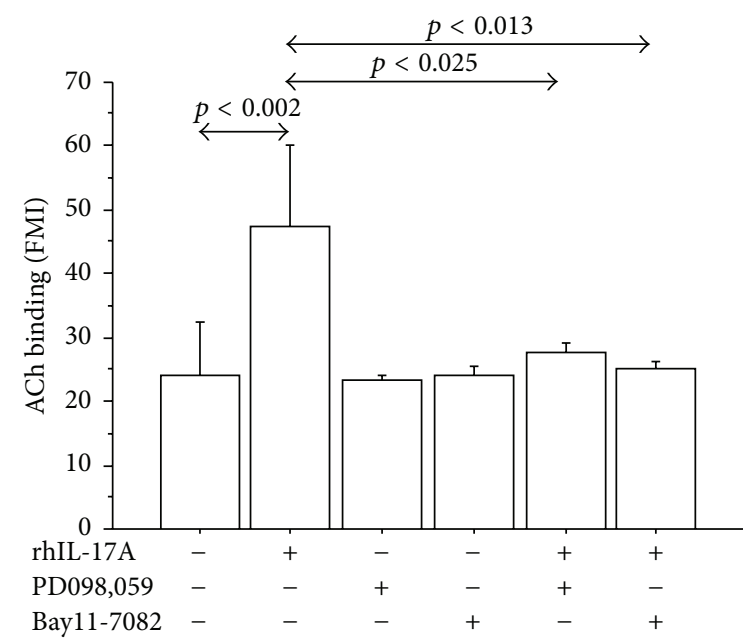

(a)

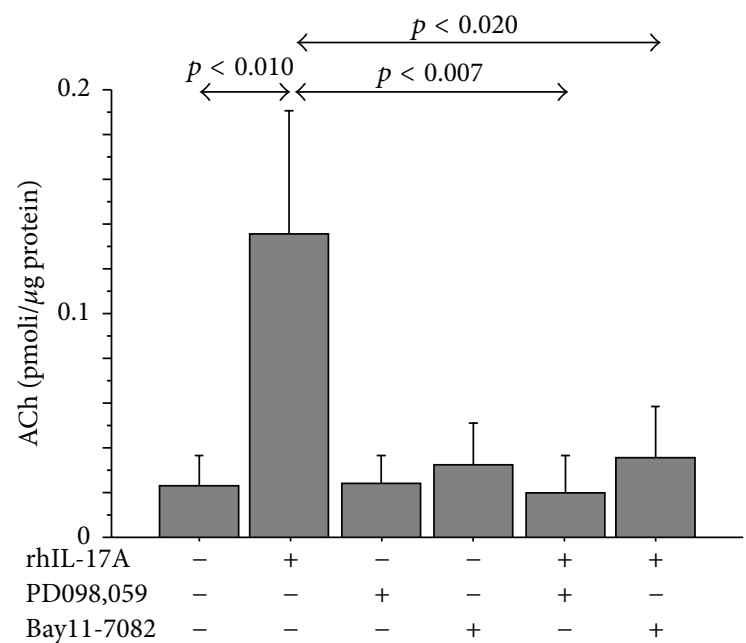

(c)

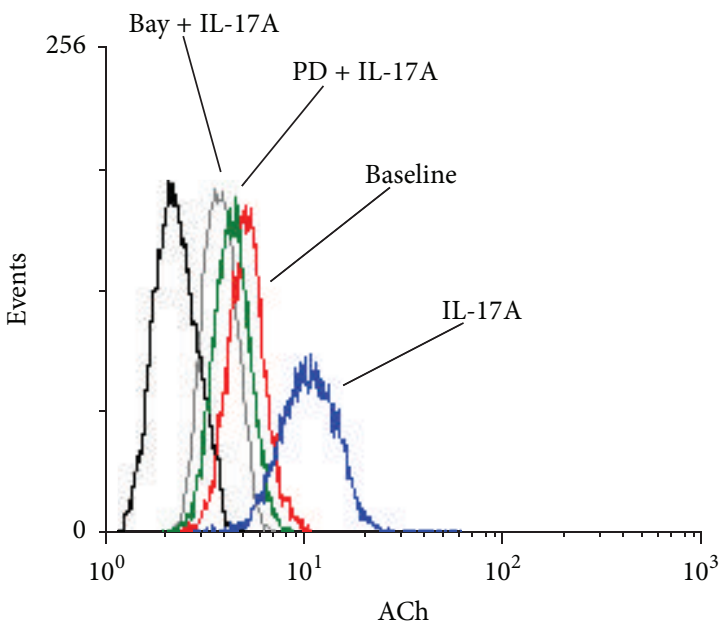

(b)

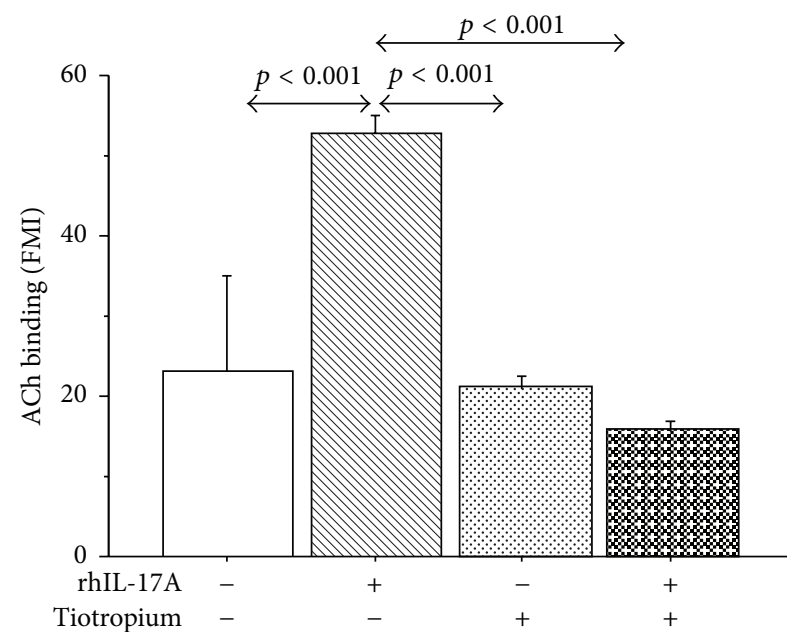

(d)

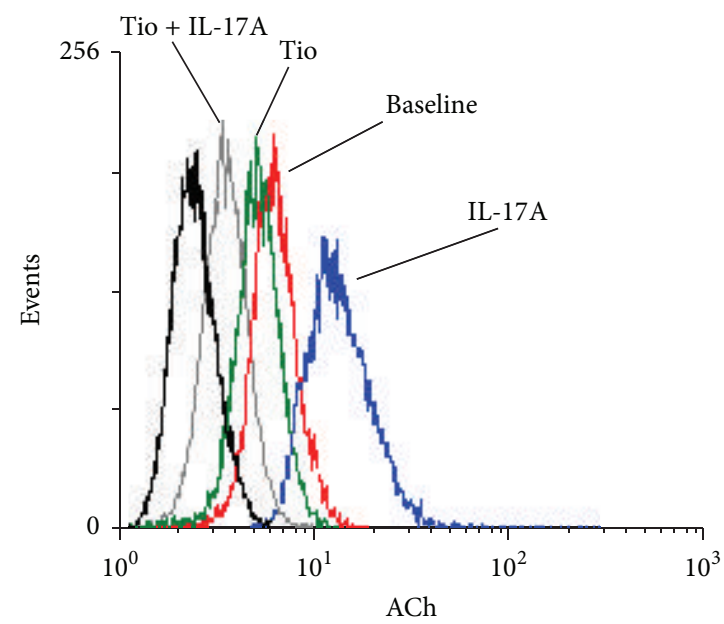

(e)

Figure 5: Effects of PD098,059 $(25 \mu \mathrm{M})$, Bayl1-7082 $(50 \mu \mathrm{M})$, and Tiotropium (100 nM) on ACh in 16-HBE cells. Cells were preincubated for $1 \mathrm{~h}$ with PD098,059 $(25 \mu \mathrm{M})$ or Bayl1-7082 $(50 \mu \mathrm{M})$ and then stimulated with rhIL-17A $20 \mathrm{ng} / \mathrm{mL}$ for $24 \mathrm{~h}$ to evaluate (a) ACh binding by flow cytometry. Bars represent mean \pm SD of fluorescence mean intensity (FMI). (b) Representative flow cytometry is shown. (c) ACh production, expressed as pmoli/ $\mu \mathrm{g}$ protein. Bars represent mean \pm SD of three different experiments. Then, $16-\mathrm{HBE}$ cells were preincubated for $1 \mathrm{~h}$ with Tiotropium (100 nM) and then stimulated with rhIL-17A $20 \mathrm{ng} / \mathrm{mL}$ for $24 \mathrm{~h}$ to evaluate (d) ACh binding by flow cytometry. Bars represent mean \pm SD of fluorescence mean intensity (FMI). (e) Representative flow cytometry is shown. Statistical analysis was performed by ANOVA test followed by Fisher's PLSD multiple comparison test. The black curve represents the anti-IgG isotype negative control antibody. 


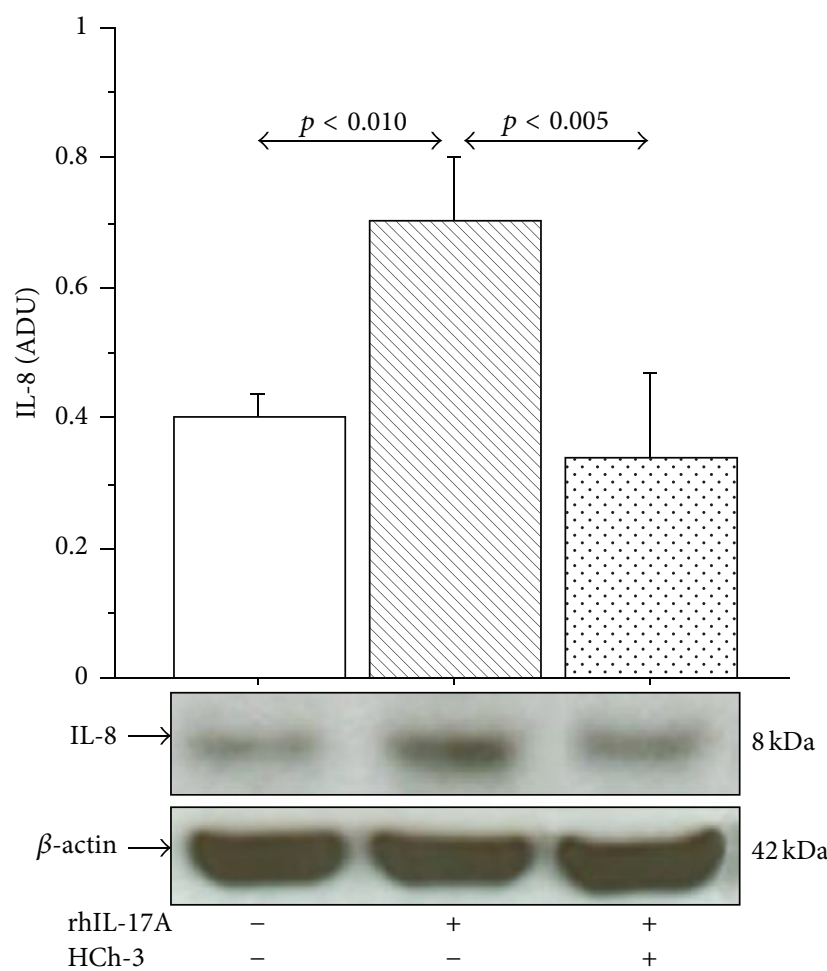

(a)

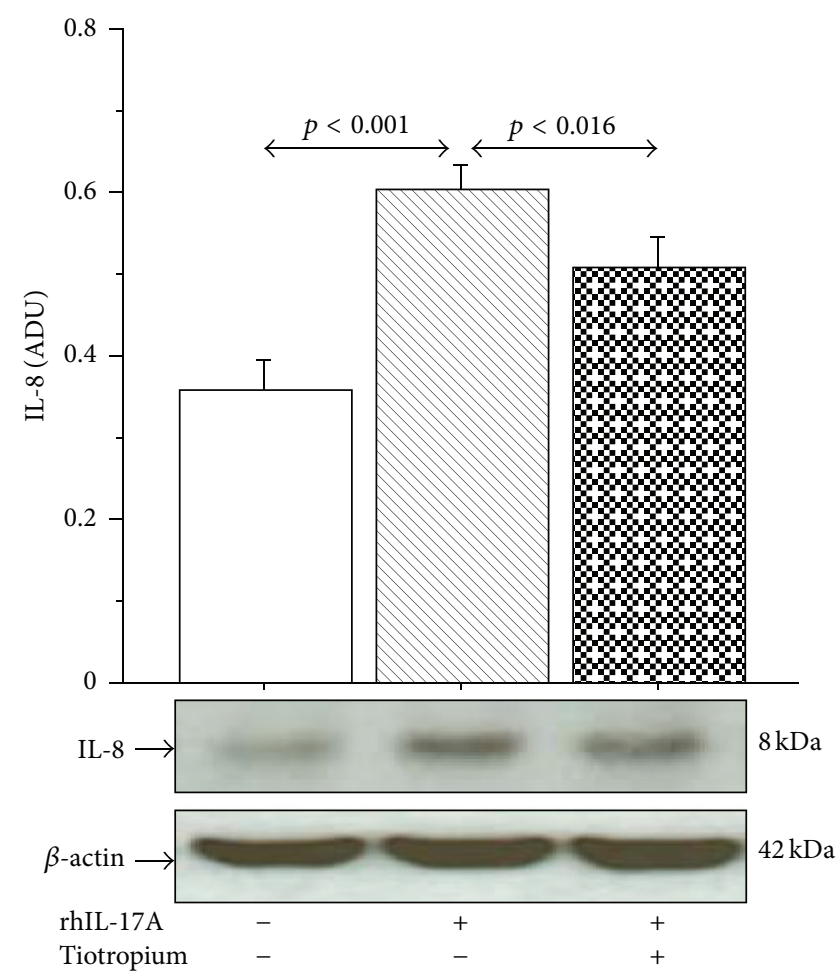

(b)

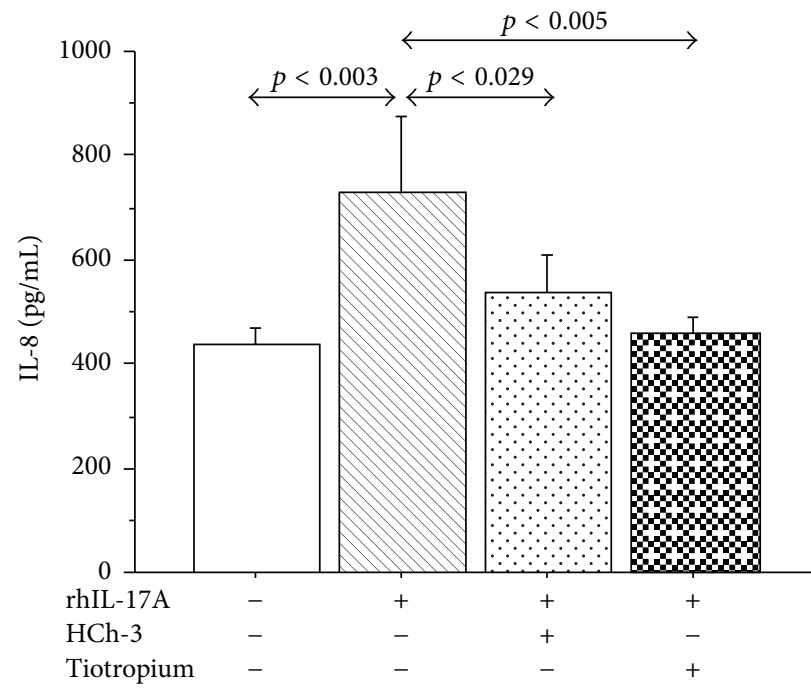

(c)

FIGURE 6: Effect of Hemicholinium-3 (HCh-3) or Tiotropium on IL-8 production in 16-HBE cells. Cells were preincubated for $1 \mathrm{~h}$ with HCh-3 $(50 \mu \mathrm{M})$ or Tiotropium $(100 \mathrm{nM})$ and then stimulated with rhIL-17A $20 \mathrm{ng} / \mathrm{mL}$ for $24 \mathrm{~h}$ to evaluate ((a)-(b)) IL-8 expression by western blot. Bars represent mean \pm SD of arbitrary densitometric units (ADU). Representative western blot analyses of IL- 8 protein and $\beta$-actin are shown. (c) IL- 8 release (pg/mL, by ELISA). The values shown are the mean \pm SD of three separate experiments. Statistical analysis was performed by ANOVA test followed by Fisher's PLSD multiple comparison test.

we found that rhIL-17A is able to increase the basal levels of ChAT protein (the enzyme involved in the synthesis of $\mathrm{ACh}$ ) synthesis, the levels of autocrine $\mathrm{ACh}$, and the related binding to cellular surface of 16-HBE cells. RhIL-17A affects the synthesis of ChAT protein also in our in vitro experiments with primary epithelial cells from normal donors
(N-HBE). These findings might suggest that Th17 immunity is involved in the ChAT/ACh activity promoting the bronchial epithelial cells activation during inflammatory process of the airways.

A relevant number of studies identified that IL-17A promotes the activation of bronchial epithelial cells through 


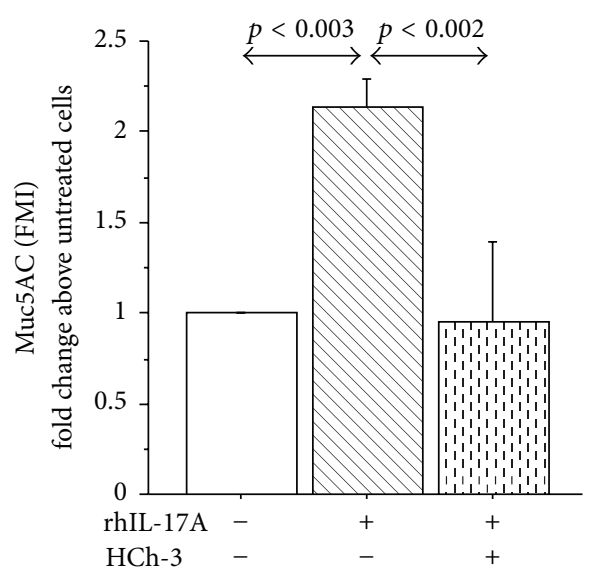

(a)

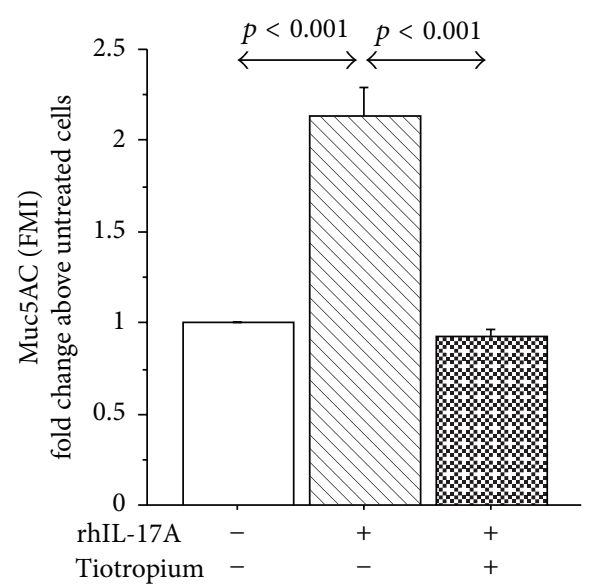

(c)

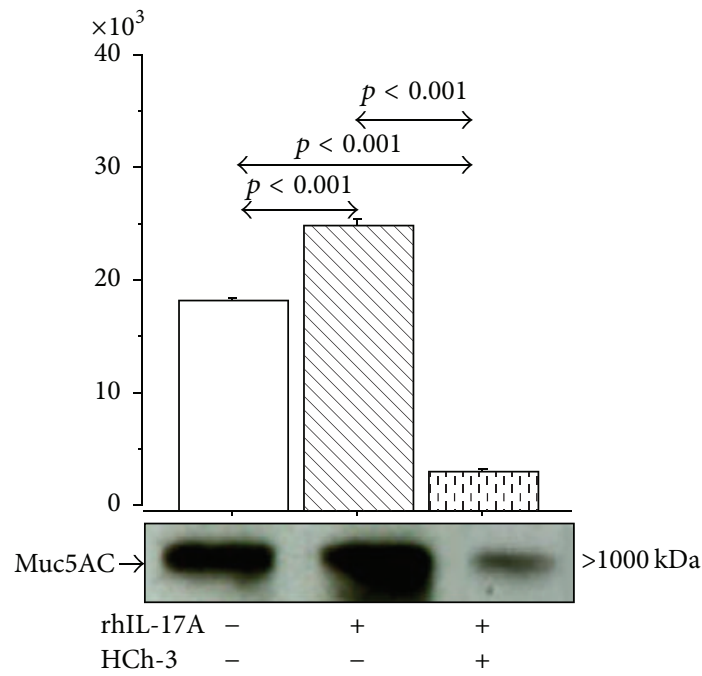

(e)

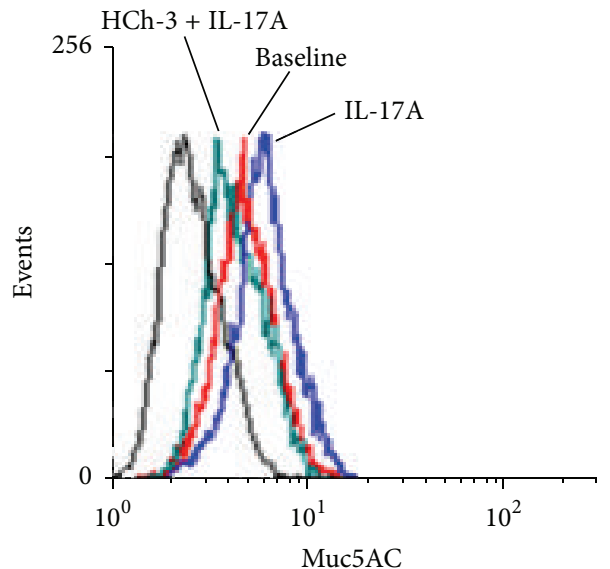

(b)

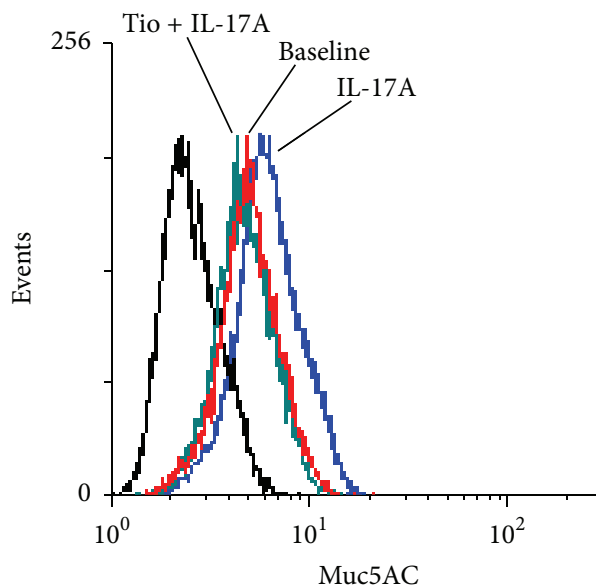

(d)

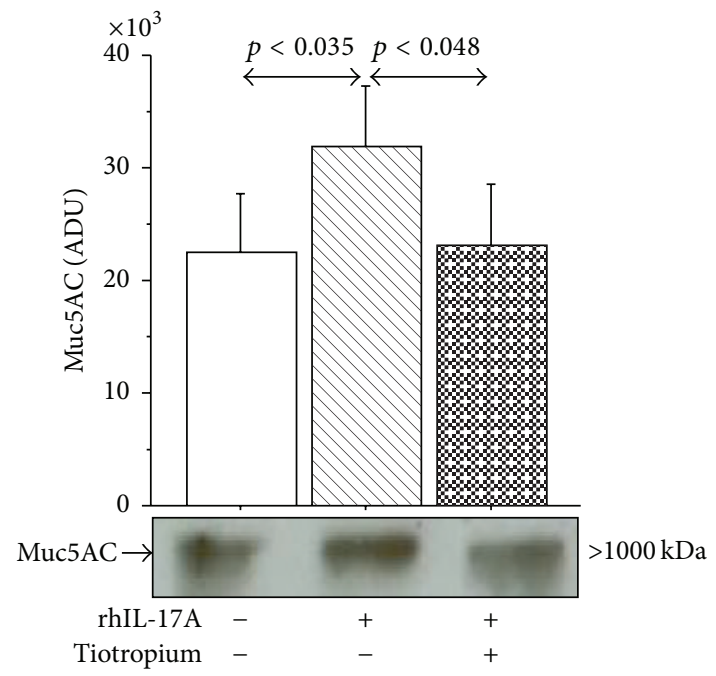

(f)

Figure 7: Effect of Hemicholinium-3 (HCh-3) or Tiotropium on Muc5AC production in 16-HBE cells. Cells were incubated for $1 \mathrm{~h}$ with HCh-3 $(50 \mu \mathrm{M})$ or Tiotropium (100 nM) before addition of rhIL-17A $20 \mathrm{ng} / \mathrm{mL}$ for $24 \mathrm{~h}$ to evaluate ((a)-(d)) Muc5AC protein expression by flow cytometry. Bars represent mean \pm SD of fluorescence mean intensity (FMI) of three separate experiments. Data were plotted as fold change compared to untreated cells. Representative flow cytometry of Muc5AC is shown. ((e)-(f)) Muc5AC protein expression by western blot. Bars represent mean \pm SD of arbitrary densitometric units (ADU) of three different experiments. Representative western blot analysis of Muc5AC protein is shown. Statistical analysis was performed by ANOVA followed by Fisher's PLSD multiple comparison test. The black curve represents the anti-IgG isotype negative control antibody. 


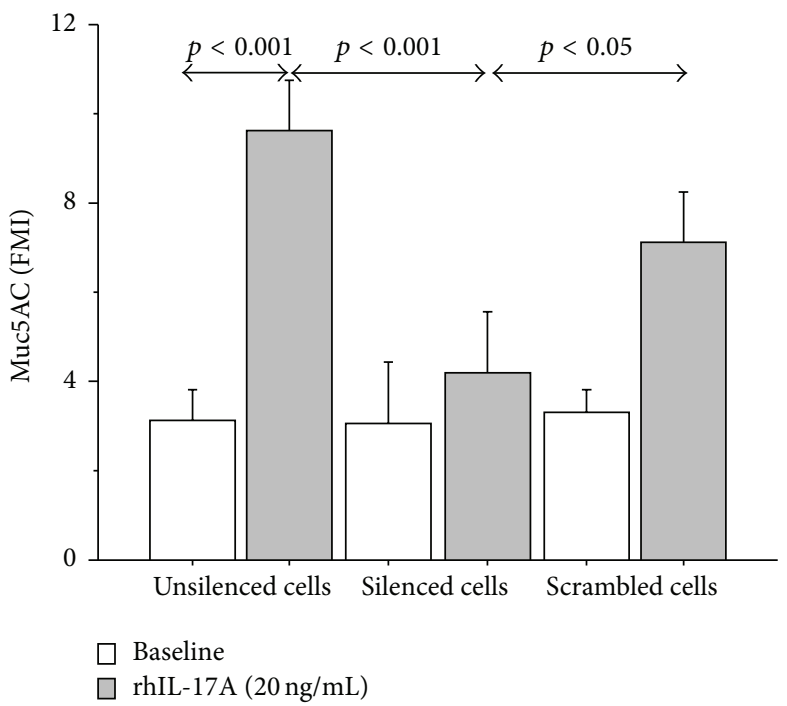

(a)

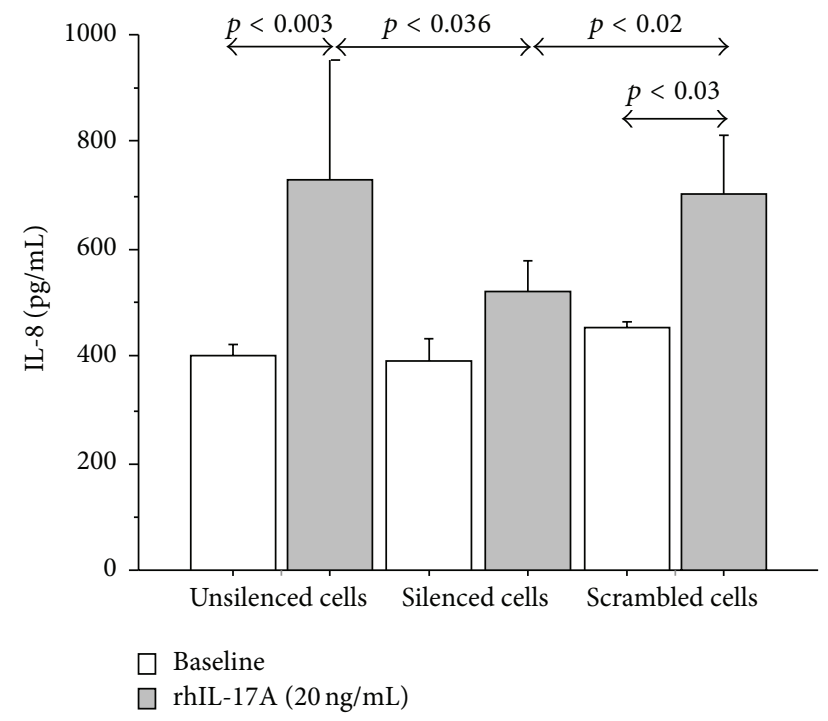

(c)

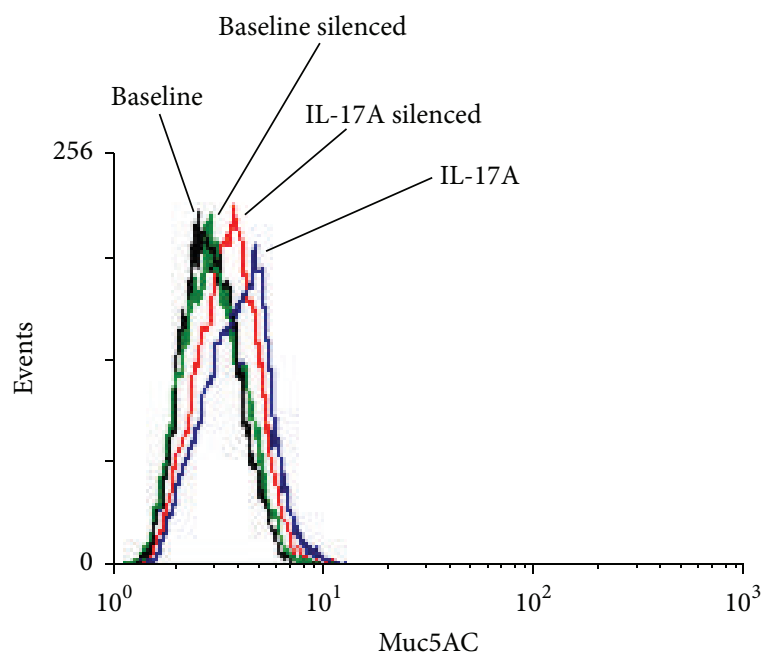

(b)

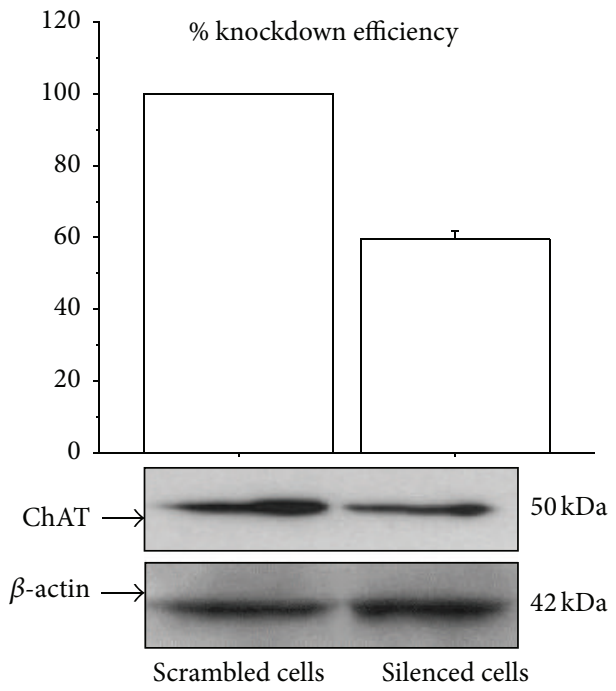

(d)

Figure 8: Silencing of ChAT mRNA reduced Muc5AC expression and IL-8 release in 16-HBE cells stimulated with rhIL-17A 20 ng/mL for $24 \mathrm{~h}$. Cells were stimulated and analyzed to evaluate (a) Muc5AC expression in unsilenced cells and in cells transfected with siRNA for ChAT or scrambled siRNA by flow cytometry. Bars represent mean \pm SD of fluorescence mean intensity (FMI) of three separate experiments. (b) Representative flow cytometry of Muc5AC is shown. (c) IL-8 release (pg/mL, by ELISA) in unsilenced cells and in cells transfected with siRNA for ChAT or scrambled siRNA. The values shown are the mean \pm SD for three separated experiments. (d) Knockdown efficiency (\%) of ChAT mRNA on ChAT protein expression. Bars represent mean \pm SD of three separate experiments. Statistical analysis was performed by ANOVA test followed by Fisher's PLSD multiple comparison test.

ERK1/2 or NFאB dependent signaling pathway $[14,15]$. The activation of MEK/ERK cascade regulates ChAT promoter via $\mathrm{NF} \kappa \mathrm{B}$ signal pathway in transfected $\mathrm{CHP126}$ neuroepithelioma cells [41]. Accordingly, we observed higher levels of ERK1/2 and $\mathrm{IkB} \alpha$ phosphorylation in 16-HBE cells stimulated with rhIL-17A $20 \mathrm{ng} / \mathrm{mL}$, suggesting the involvement of MEK/ERK and NF $\kappa$ B pathway activation in our in vitro model. Furthermore, looking at NFאB-p65 in nuclear extract (as upstream of pIkB), we underlined an increase of the nuclear translocation of $\mathrm{NF} \kappa \mathrm{B}$ in $16-\mathrm{HBE}$ cells stimulated with IL-17A $20 \mathrm{ng} / \mathrm{mL}$. These findings might provide evidences for the involvement of $\mathrm{NF} \kappa \mathrm{B}$ pathway in bronchial epithelial cells stimulated with IL-17A. To demonstrate that rhIL-17A regulates ChAT synthesis via MEK/ERK cascade and via NFKB pathway, we preincubated with PD098,059 (inhibitor of MAPKK activation) and Bayll-7082 (inhibitor of $\mathrm{IkB} \alpha$ phosphorylation) the $16-\mathrm{HBE}$ cells stimulated with rhIL-17A. The use of the specific inhibitors reduced the levels of ChAT protein synthesis and ACh production and binding in the cells stimulated with rhIL-17A suggesting the involvement of MEK/ERK cascade and via NF $\kappa B$ pathway in this mechanism of synthesis. However, we observed 


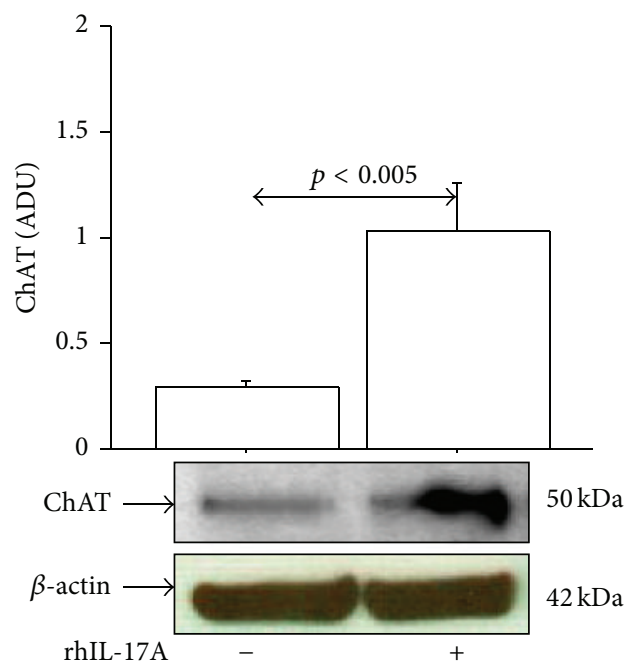

(a)

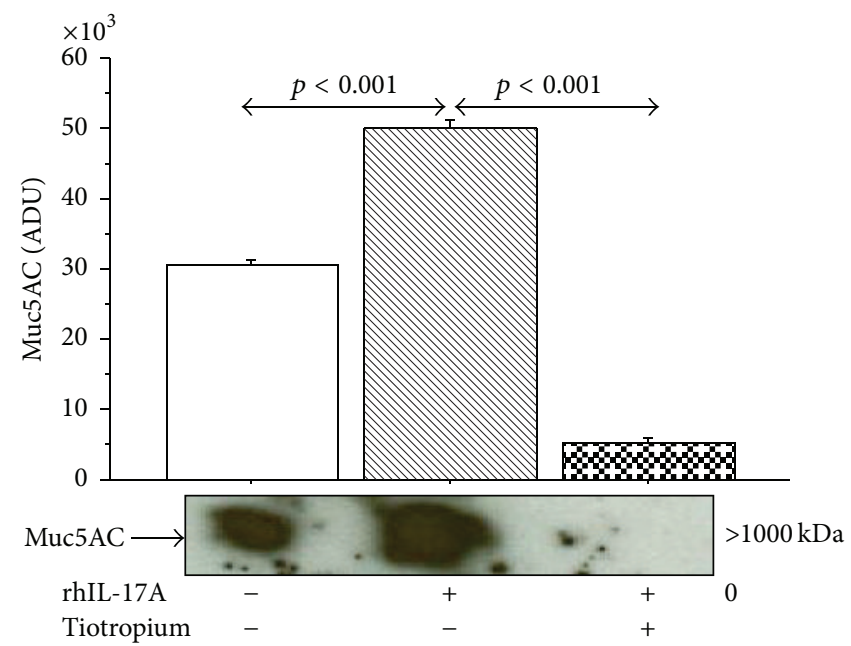

(c)

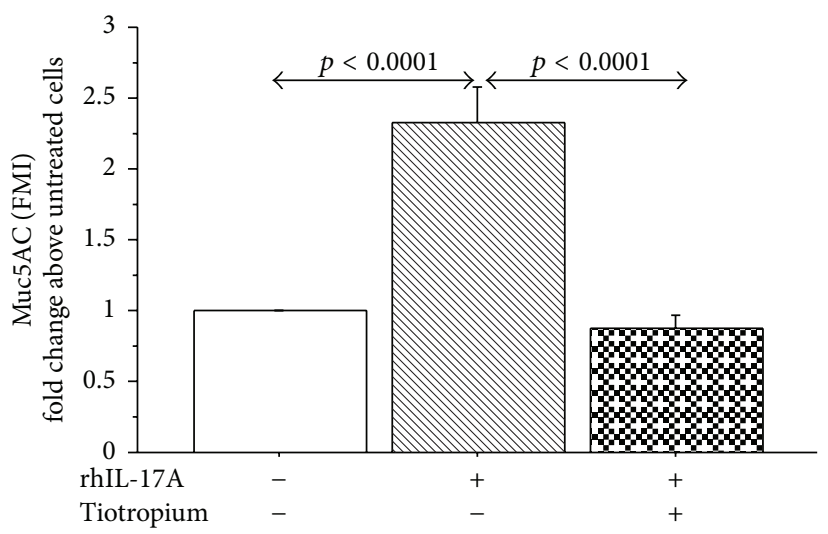

(b)

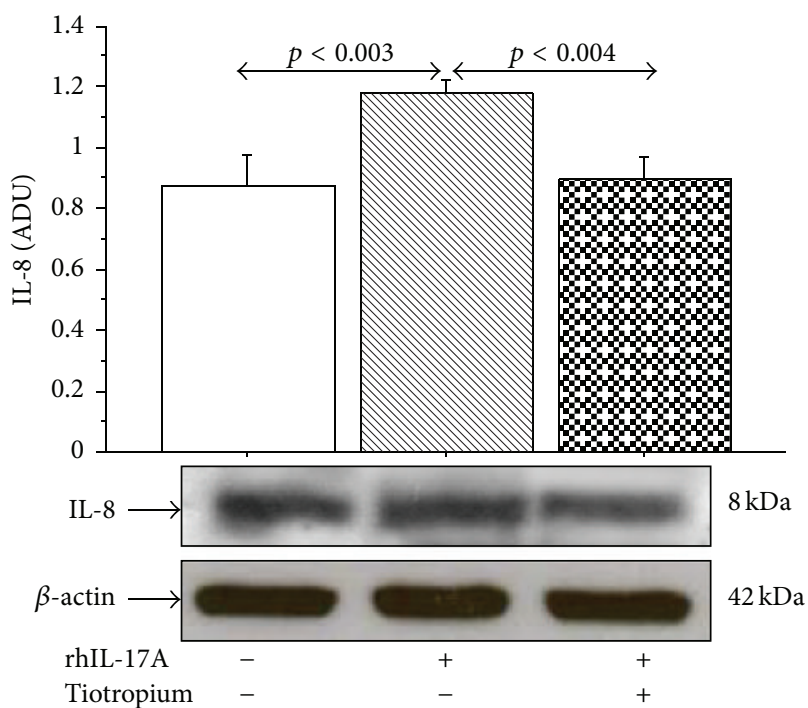

(d)

Figure 9: Effect of Tiotropium on ChAT, Muc5AC, and IL-8 in N-HBE cells. Cells were incubated for $1 \mathrm{~h}$ with Tiotropium (100 nM) before addition of rhIL-17A $20 \mathrm{ng} / \mathrm{mL}$ for $24 \mathrm{~h}$ to evaluate (a) ChAT protein expression by western blot. Bars represent mean \pm SD of arbitrary densitometric units (ADU). Representative western blot analysis of ChAT protein and $\beta$-actin is shown. (b) Muc5AC protein expression by flow cytometry. Bars represent mean \pm SD of fluorescence mean intensity (FMI) of three separate experiments and were plotted as fold change compared to untreated cells. (c) Muc5AC protein expression by western blot. Bars represent mean \pm SD of arbitrary densitometric units (ADU) of three different experiments. Representative western blot analysis of Muc5AC protein is shown. (d) IL-8 expression by western blot. Bars represent mean \pm SD of arbitrary densitometric units (ADU). Representative western blot analyses of IL- 8 protein and $\beta$-actin are shown. Statistical analysis was performed by ANOVA followed by Fisher's PLSD multiple comparison test. $p<0.05$ was accepted as statistically significant.

the dose-response curve of rhIL-17A peaks at $20 \mathrm{ng} / \mathrm{mL}$ for ERK1/2 and $\operatorname{IkB} \alpha$ signaling to shape at the concentration of IL-17A $50 \mathrm{ng} / \mathrm{mL}$. In contrast to these data, we showed persistence of ChAT synthesis and ACh production and binding. These findings might suggest that the higher concentration of rhIL-17A might be involved in the ChAT synthesis, independently of the MEK/ERK cascade and NF $\kappa$ B pathway, by the activation of other intracellular signal pathways. However, in this study we focused our attention on the effect of rhIL-17A
$20 \mathrm{ng} / \mathrm{mL}$. Nevertheless, we suggest that further studies will be necessary to better clarify the role of intracellular signal pathway involved in ChAT synthesis and autocrine ACh activity of bronchial epithelial cells stimulated with rhIL-17A $50 \mathrm{ng} / \mathrm{mL}$.

Th17 immunity has an emerging role in the induction of neutrophilic airway inflammation $[9,12,13]$ and Muc5AC production [15]. The reduced sensitivity to GCs related to Th17 immunity has been clinically associated with 
neutrophilic airway inflammation $[42,43]$, but it is still largely unclear which cellular and molecular mechanisms contribute to this phenomenon. IL-17A activated the p38, extracellular signal-related kinase (ERK), and phosphoinositide-3-kinase (PI3K) pathways inducing GC insensitivity [34]. Furthermore, mechanisms whereby pharmacological agents such as glucocorticoids repress mucin gene expression are not well studied, although they might be important for formulating therapeutic interventions in chronic lung diseases [44]. Preclinical studies have demonstrated that stimulation with cholinergic agonists (ACh, methacholine) or cholinergic antagonists (atropine), targeting muscarinic receptors, increases mucociliary clearance [24, 45, 46]. Accordingly, anticholinergic drugs block muscarinic receptors activity on airway secretory cells and smooth muscle and so, theoretically, may reduce vagal tone and mucus secretion in COPD facilitating cough-induced mucus clearance $[25,26]$. Consistent with this suggestion is the observation that Tiotropium reduces levels of mucus secretion in patients with COPD [47]. Furthermore, Tiotropium reduces exacerbation frequency in COPD, but this effect does not appear to be due to a reduction in IL-8 systemic inflammation [48] and is able to control IL-8 release in epithelial cells in vitro [22, 49]. In this scenario, we speculate that the blockade of IL-17A downstream, regarding ChAT synthesis, and autocrine ACh production might represent a new strategy for therapeutic intervention in GC insensitivity of airway inflammation using anticholinergic drugs. Accordingly, we showed that the use of Tiotropium is able to reduce autocrine ACh binding. These results suggest the involvement of mAChRs in the activation of bronchial epithelial cells stimulated with IL17A. Furthermore, we observed that the use of muscarinic receptor antagonists such as Tiotropium is able to control the Muc5AC and IL-8 production blocking the activity of ACh bound to mAChRs generated by IL-17A in bronchial epithelial cells. We support this observation showing the effect of HCh-3 (choline uptake blocker) that, blocking the synthesis of autocrine ACh, reduced the Muc5AC and IL8 production in $16-\mathrm{HBE}$ cells stimulated with rhIL-17A. Finally, we observed that the ChAT enzyme RNA interference promoted the reduction of Muc5AC and IL- 8 production in the 16-HBE cells stimulated with rhIL-17A rather than in both unsilenced and scrambled cells stimulated with rhIL17A. These results might suggest the potential involvement of ChAT/ACh pathway in the regulation of mucin production and inflammation in bronchial epithelial cells during chronic airway disease. However, rhIL-17A did not affect the expression of mAChRs (M1-3) in 16-HBE cells (data not shown). In this scenario, our in vitro model suggests the potential relevant contribution of anticholinergic drugs to the blockade of mucus and inflammatory secretion during COPD exacerbations. Accordingly, we showed that Tiotropium reduced MUC5AC and IL-8 production in the experiment performed with $16-\mathrm{HBE}$ and primary N-HBE cells stimulated with rhIL17A. Nevertheless, further "in vivo" clinical study should be necessary to clarify the role of anticholinergic drugs in the control of mucus and inflammatory mediator secretion from bronchial epithelial cells during IL-17A mediated airway inflammation.

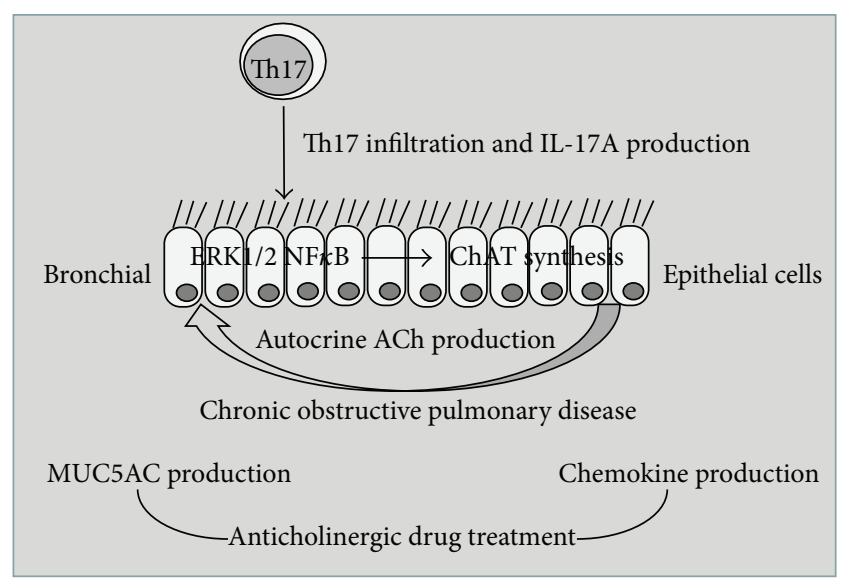

FIGURE 10: Autocrine acetylcholine induced by IL-17A, via NF $\kappa$ B and ERK1/2 pathway activation, promotes MUC5AC and IL-8 synthesis in bronchial epithelial cells. Effect of anticholinergic drugs.

\section{Conclusions}

To our knowledge, this is the first descriptive study demonstrating the involvement of IL-17A in the induction of the ChAT/ACh activity in bronchial epithelial cells promoting inflammation and mucus secretion in the airways. The ability of muscarinic receptor antagonists, including Tiotropium, to modulate IL-17A activity might open up perspectives for novel therapeutic strategies in the control of Th17 immunity during the airway inflammation and the mucus secretion of COPD patients (Figure 10).

\section{Abbreviations}

COPD:

Chronic Obstructive Pulmonary

IL-17A: Interleukin-17A

ChAT:

Choline Acetyl-Transferase

ACh:

Acetylcholine

MRs:

Muc5AC:

Muscarinic receptors

IL-8:

PD098,059:

Mucin 5 AC

Interleukin-8

Bayl1-7082: $\quad$ (E)-3-(4-

Methylphenylsulfonyl)-2propenenitrile, $\mathrm{C}_{10} \mathrm{H}_{9} \mathrm{NO}_{2} \mathrm{C}$

HCh-3: Hemicholinium-3, $\mathrm{C}_{24} \mathrm{H}_{34} \mathrm{Br}_{2} \mathrm{~N}_{2} \mathrm{O}_{4}$

Tiotropium, Spiriva: $(1 \alpha, 2 \beta, 4 \beta, 5 \alpha$, $7 \beta)-7-[($ Hydroxydi-2thienylacetyl)oxy]-9,9dimethyl-3-oxa-9azoniatricyclo[3.3.1.02,4], $\mathrm{C}_{19} \mathrm{H}_{22} \mathrm{NO}_{4} \mathrm{~S}_{2} \mathrm{Br}_{-} \mathrm{H}_{2} \mathrm{O}$. 


\section{Competing Interests}

The author of the paper Michael Paul Pieper is employee of Boehringer Ingelheim Pharma GmbH \& Co. KG. There is no other conflict of interests for this study.

\section{Authors' Contributions}

The authors Angela Marina Montalbano, Giusy Daniela Albano, and Mirella Profita conceived the study and designed the experiments. Anna Bonanno, Loredana Riccobono, Giulia Anzalone, Caterina Di Sano, Liboria Siena, and Maria Ferraro performed the technical procedures. Mirella Profita provided the interpretation of data and wrote the paper. Michael Paul Pieper and Mark Gjomarkaj revised the final draft of the paper. All authors read and approved the final version of the paper.

\section{Acknowledgments}

The authors thank the Italian National Research Council and Boehringer Ingelheim Pharma GmbH \& Co. KG. The study was supported by an unrestricted educational grant from Boehringer Ingelheim Pharma GmbH \& Co. KG (Contract no. 43028659).

\section{References}

[1] M. Profita, G. Chiappara, F. Mirabella et al., "Effect of cilomilast (Ariflo) on TNF- $\alpha$, IL-8, and GM-CSF release by airway cells of patients with COPD," Thorax, vol. 58, no. 7, pp. 573-579, 2003.

[2] K. M. Beeh, O. Kornmann, R. Buhl, S. V. Culpitt, M. A. Giembycz, and P. J. Barnes, "Neutrophil chemotactic activity of sputum from patients with COPD: role of interleukin 8 and leukotriene B4," Chest, vol. 123, no. 4, pp. 1240-1247, 2003.

[3] S. Oudin and J. Pugin, "Role of MAP kinase activation in interleukin- 8 production by human BEAS-2B bronchial epithelial cells submitted to cyclic stretch," American Journal of Respiratory Cell and Molecular Biology, vol. 27, no. 1, pp. 107-114, 2002.

[4] J. Li, S. Kartha, S. Iasvovskaia et al., "Regulation of human airway epithelial cell IL-8 expression by MAP kinases," American Journal of Physiology - Lung Cellular and Molecular Physiology, vol. 283, no. 4, pp. L690-L699, 2002.

[5] K. Takeyama, B. Jung, J. J. Shim et al., "Activation of epidermal growth factor receptors is responsible for mucin synthesis induced by cigarette smoke," American Journal of PhysiologyLung Cellular and Molecular Physiology, vol. 280, no. 1, pp. L165L172, 2001.

[6] D. F. Rogers, "Mucociliary dysfunction in COPD: effect of current pharmacotherapeutic options," Pulmonary Pharmacology and Therapeutics, vol. 18, no. 1, pp. 1-8, 2005.

[7] H. Ikeuchi, T. Kuroiwa, N. Hiramatsu et al., "Expression of interleukin-22 in rheumatoid arthritis: potential role as a proinflammatory cytokine," Arthritis and Rheumatism, vol. 52, no. 4, pp. 1037-1046, 2005.

[8] K. Wolk, E. Witte, K. Warszawska et al., "The Th17 cytokine IL22 induces IL-20 production in keratinocytes: a novel immunological cascade with potential relevance in psoriasis," European Journal of Immunology, vol. 39, no. 12, pp. 3570-3581, 2009.
[9] F. Alcorn, C. R. Crowe, and J. K. Kolls, "TH17 cells in asthma and COPD," Annual Review of Physiology, vol. 72, no. 2010, pp. 495-516, 2010.

[10] G. D. Albano, C. Di Sano, A. Bonanno et al., "Th17 immunity in children with allergic asthma and rhinitis: a pharmacological approach," PLoS ONE, vol. 8, no. 4, Article ID e58892, 2013.

[11] H. L. Tan and M. Rosenthal, "IL-17 in lung disease: friend or foe?" Thorax, vol. 68, no. 8, pp. 788-790, 2013.

[12] S. Molet, Q. Hamid, F. Davoine et al., "IL-17 is increased in asthmatic airways and induces human bronchial fibroblasts to produce cytokines," Journal of Allergy and Clinical Immunology, vol. 108, no. 3, pp. 430-438, 2001.

[13] M. Kawaguchi, F. Kokubu, H. Kuga et al., "Modulation of bronchial epithelial cells by IL-17," Journal of Allergy and Clinical Immunology, vol. 108, no. 5, pp. 804-809, 2001.

[14] D. Inoue, M. Numasaki, M. Watanabe et al., "IL-17A promotes the growth of airway epithelial cells through ERK-dependent signaling pathway," Biochemical and Biophysical Research Communications, vol. 347, no. 4, pp. 852-858, 2006.

[15] T. Fujisawa, S. Velichko, P. Thai, L. Y. Hung, F. Huang, and R. Wu, "Regulation of airway MUC5AC expression by IL-1beta and IL-17A; the NF-kappaB paradigm," Journal of Immunology, vol. 183, no. 10, pp. 6236-6243, 2009.

[16] R. Gosens, J. Zaagsma, M. Grootte Bromhaar, A. Nelemans, and H. Meurs, "Acetylcholine: a novel regulator of airway smooth muscle remodelling?" European Journal of Pharmacology, vol. 500, no. 1-3, pp. 193-201, 2004.

[17] S. Koyama, E. Sato, H. Nomura, K. Kubo, S. Nagai, and T. Izumi, "Acetylcholine and substance P stimulate bronchial epithelial cells to release eosinophil chemotactic activity," Journal of Applied Physiology, vol. 84, no. 5, pp. 1528-1534, 1998.

[18] E. Sato, S. Koyama, Y. Okubo, K. Kubo, and M. Sekiguchi, "Acetylcholine stimulates alveolar macrophages to release inflammatory cell chemotactic activity," American Journal of Physiology_Lung Cellular and Molecular Physiology, vol. 274, no. 6, pp. L970-L979, 1998.

[19] M. Profita, R. Di Giorgi, A. Sala et al., "Muscarinic receptors, leukotriene B4 production and neutrophilic inflammation in COPD patients," Allergy, vol. 60, no. 11, pp. 1361-1369, 2005.

[20] K. S. Kummer and U. Pfeil, "The epithelial cholinergic system of the airways," Histochemistry and Cell Biology, vol. 130, no. 2, pp. 219-234, 2008.

[21] R. Gosens, J. Zaagsma, H. Meurs, and A. J. Halayko, "Muscarinic receptor signaling in the pathophysiology of asthma and COPD," Respiratory Research, vol. 7, article 73, 2006.

[22] M. Profita, A. Bonanno, L. Siena et al., "Acetylcholine mediates the release of IL-8 in human bronchial epithelial cells by a NFkB/ERK-dependent mechanism," European Journal of Pharmacology, vol. 582, no. 1-3, pp. 145-153, 2008.

[23] M. Profita, G. D. Albano, L. Riccobono et al., "Increased levels of Th17 cells are associated with non-neuronal acetylcholine in COPD patients," Immunobiology, vol. 219, no. 5, pp. 392-401, 2014.

[24] L. A. Gatto, "Cholinergic and adrenergic stimulation of mucociliary trasport in the rat trachea," Respiration Physiology, vol. 92, no. 2, pp. 209-217, 1993.

[25] S. F. Abad, J. Novalbos, S. S. Gallego, and M. A. Galvez Mugica, "Regulation of bronchial tone in chronic obstructive pulmonary disease (COPD): role of muscarinic receptors] Regulacion del tono bronquial enlaenfermedad pulmonary obstructive cronica (EPOC): papeldelos receptors muscarinicos," Anales de Medicina Interna, vol. 20, pp. 201-205, 2003. 
[26] F. R. Coulson and A. D. Fryer, "Muscarinic acetylcholine receptors and airway diseases," Pharmacology and Therapeutics, vol. 98, no. 1, pp. 59-69, 2003.

[27] A. Bruno, E. Pace, P. Chanez et al., "Leptin and leptin receptor expression in asthma," Journal of Allergy and Clinical Immunology, vol. 124, no. 2, pp. 230-237, 2009.

[28] M. Profita, A. Bonanno, L. Siena et al., "Smoke, choline acetyltransferase, muscarinic receptors, and fibroblast proliferation in chronic obstructive pulmonary disease," Journal of Pharmacology and Experimental Therapeutics, vol. 329, no. 2, pp. 753-763, 2009.

[29] T. D. Schmittgen and K. J. Livak, "Analyzing real-time PCR data by the comparative $C_{\mathrm{T}}$ method," Nature Protocols, vol. 3, no. 6, pp. 1101-1108, 2008.

[30] M. Profita, A. Bonanno, A. M. Montalbano et al., "Cigarette smoke extract activates human bronchial epithelial cells affecting non-neuronal cholinergic system signalling in vitro," Life Sciences, vol. 89, no. 1-2, pp. 36-43, 2011.

[31] S. Kim, A. J. Schein, and J. A. Nadel, "E-cadherin promotes EGFR-mediated cell differentiation and MUC5AC mucin expression in cultured human airway epithelial cells," American Journal of Physiology_Lung Cellular and Molecular Physiology, vol. 289, no. 6, pp. L1049-L1060, 2005.

[32] M. Mata, B. Sarriá, A. Buenestado, J. Cortijo, M. Cerdá, and E. J. Morcillo, "Phosphodiesterase 4 inhibition decreases MUC5AC expression induced by epidermal growth factor in human airway epithelial cells," Thorax, vol. 60, no. 2, pp. 144-152, 2005.

[33] M. E. Lidell, J. Bara, and G. C. Hansson, "Mapping of the $45 \mathrm{M} 1$ epitope to the C-terminal cysteine-rich part of the human MUC5AC mucin," FEBS Journal, vol. 275, no. 3, pp. 481-489, 2008.

[34] G. J. Zijlstra, N. H. T. Ten Hacken, R. F. Hoffmann, A. J. M. van Oosterhout, and I. H. Heijink, "Interleukin-17A induces glucocorticoid insensitivity in human bronchial epithelial cells," European Respiratory Journal, vol. 39, no. 2, pp. 439-445, 2012.

[35] D. Gosens, H. Meurs, D. K. Ninaber et al., "Muscarinic M3 receptor stimulation increases cigarette smoke-induced IL-8 secretion by human airway smooth muscle cells," European Respiratory Journal, vol. 34, pp. 1436-1443, 2009.

[36] J. Qian, V. Galitovskiy, A. I. Chernyavsky, S. Marchenko, and S. A. Grando, "Plasticity of the murine spleen T-cell cholinergic receptors and their role in in vitro differentiation of nave CD4 T cells toward the Th1, Th2 and Th17 lineages," Genes and Immunity, vol. 12, no. 3, pp. 222-230, 2011.

[37] A. Lindén, H. Hoshino, and M. Laan, "Airway neutrophils and interleukin-17," European Respiratory Journal, vol. 15, no. 5, pp. 973-977, 2000.

[38] L.-Y. Hung, S. Velichko, F. Huang, P. Thai, and R. Wu, "Regulation of airway innate and adaptive immune responses: the IL-17 paradigm," Critical Reviews in Immunology, vol. 28, no. 4, pp. 269-279, 2008.

[39] B. M. Vanaudenaerde, S. E. Verleden, R. Vos et al., "Innate and adaptive interleukin-17-producing lymphocytes in chronic inflammatory lung disorders," American Journal of Respiratory and Critical Care Medicine, vol. 183, no. 8, pp. 977-986, 2011.

[40] A. M. Montalbano, L. Riccobono, L. Siena et al., "Cigarette smoke affects IL-17A, IL-17F and IL-17 receptor expression in the lung tissue: Ex vivo and in vitro studies," Cytokine, vol. 76, no. 2, pp. 391-402, 2015.

[41] E. Espinos and M. J. Weber, "Activation of the MAP kinase cascade by histone deacetylase inhibitors is required for the stimulation of choline acetyltransferase gene promoter," Molecular Brain Research, vol. 56, no. 1-2, pp. 118-124, 1998.

[42] D. C. Cowan, J. O. Cowan, R. Palmay, A. Williamson, and D. R. Taylor, "Effects of steroid therapy on inflammatory cell subtypes in asthma," Thorax, vol. 65, no. 5, pp. 384-390, 2010.

[43] S. A. Little, G. W. Chalmers, K. J. MacLeod, N. C. Thomson, and C. McSharry, "Non-invasive markers of airway inflammation as predictors of oral steroid responsiveness in asthma," Thorax, vol. 55, no. 3, pp. 232-234, 2000.

[44] Y. Chen, A. M. Watson, C. D. Williamson et al., "Glucocorticoid receptor and histone deacetylase-2 mediate dexamethasoneinduced repression of MUC5AC gene expression," American Journal of Respiratory Cell and Molecular Biology, vol. 47, no. 5, pp. 637-644, 2012.

[45] P. Camner, K. Strandberg, and K. Philipson, "Increased mucociliary transport by cholinergic stimulation," Archives of Environmental Health, vol. 29, no. 4, pp. 220-224, 1974.

[46] J. Berger, R. E. Albert, K. Sanborn, and M. Lippmann, "Effects of atropine and methacholine on deposition and clearance of inhaled particles in the donkey," Journal of Toxicology and Environmental Health, vol. 4, no. 4, pp. 587-604, 1978.

[47] J. Tamaoki, A. Chiyotani, E. Tagaya, N. Sakai, and K. Konno, "Effect of long term treatment with oxitropium bromide on airway secretion in chronic bronchitis and diffuse panbronchiolitis," Thorax, vol. 49, no. 6, pp. 545-548, 1994.

[48] D. J. Powrie, T. M. A. Wilkinson, G. C. Donaldson et al., "Effect of tiotropium on sputum and serum inflammatory markers and exacerbations in COPD," European Respiratory Journal, vol. 30, no. 3, pp. 472-478, 2007.

[49] I. Suzaki, K. Asano, Y. Shikama, T. Hamasaki, A. Kanei, and H. Suzaki, "Suppression of IL-8 production from airway cells by tiotropium bromide in vitro," The International Journal of Chronic Obstructive Pulmonary Disease, vol. 6, pp. 439-448, 2011. 


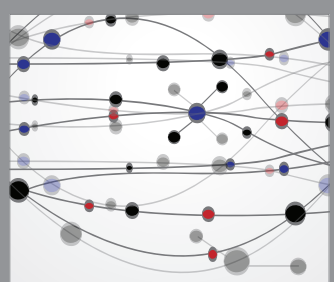

The Scientific World Journal
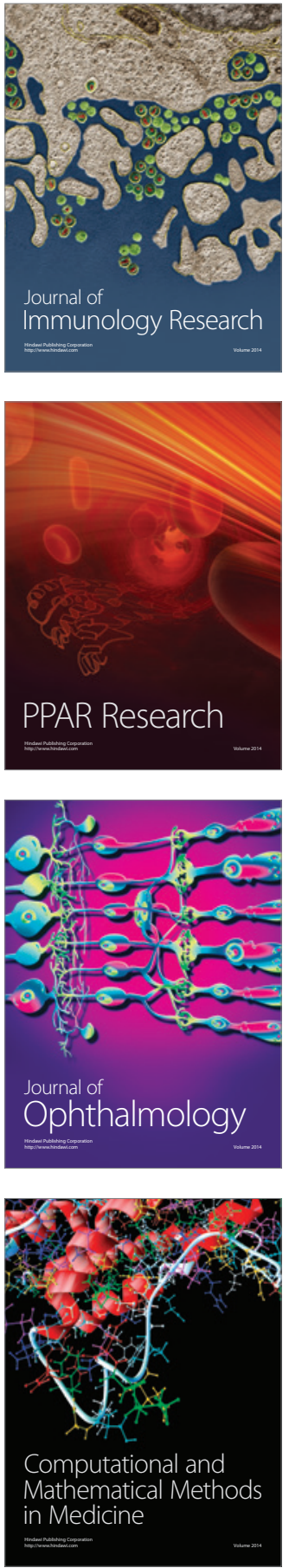

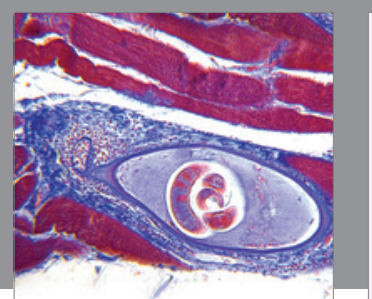

Gastroenterology Research and Practice

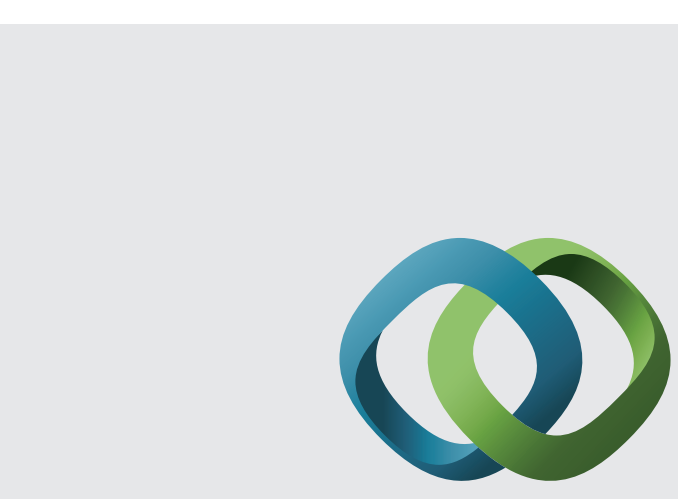

\section{Hindawi}

Submit your manuscripts at

http://www.hindawi.com
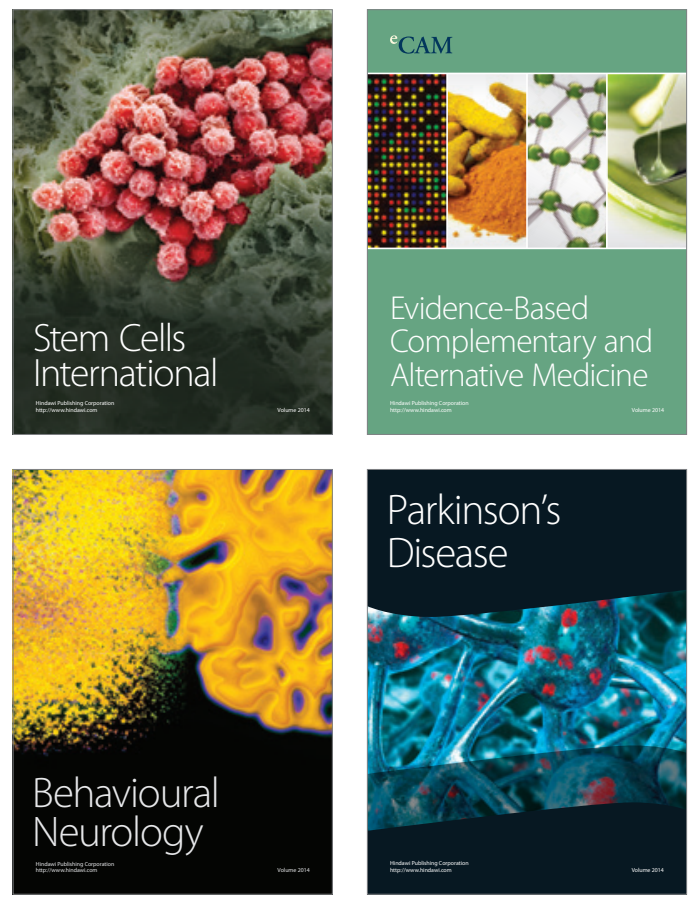
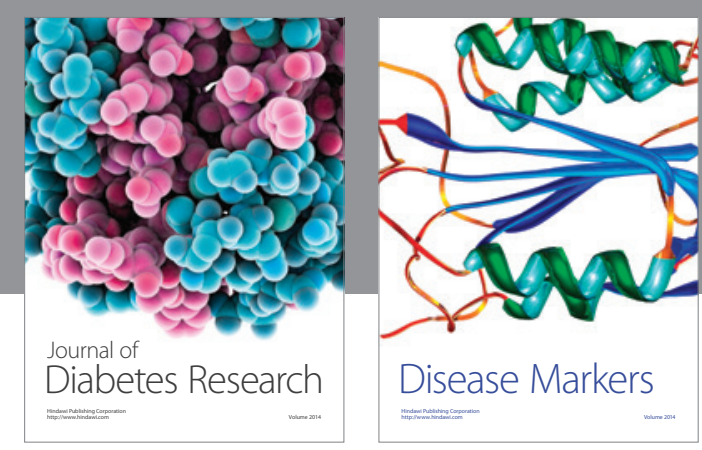

Disease Markers
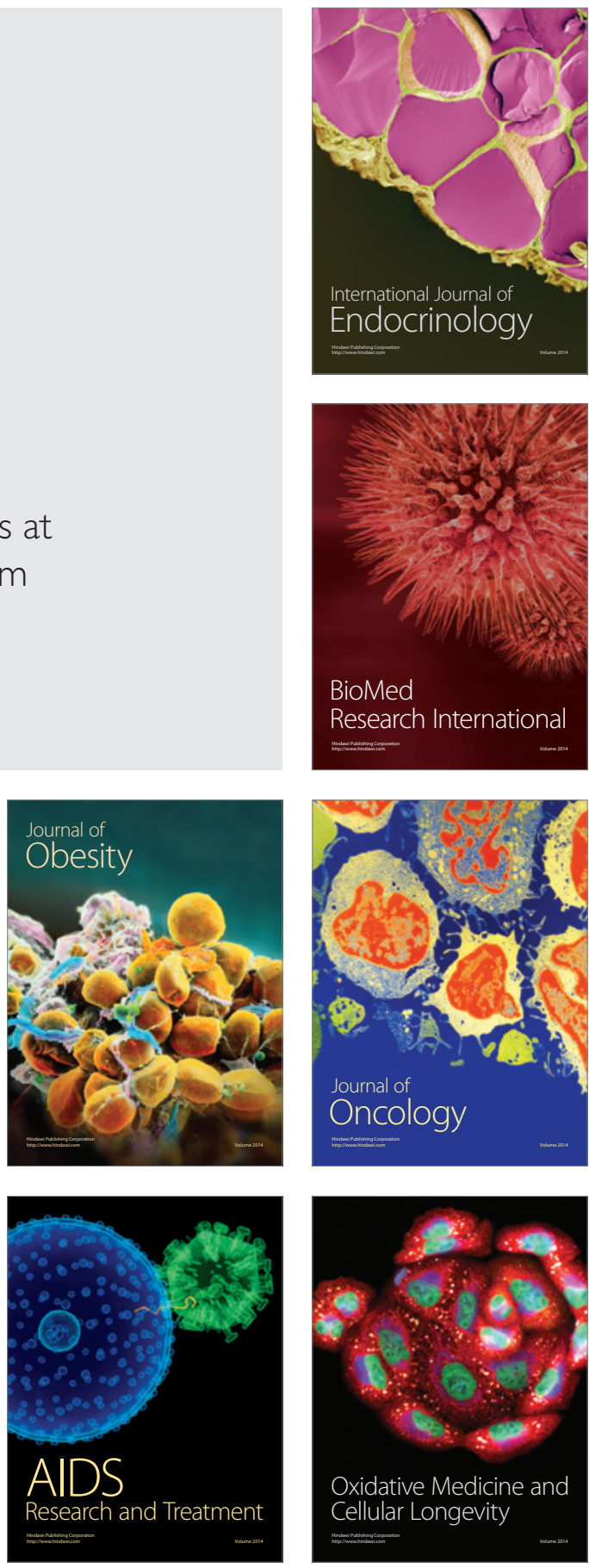